MAEGORZATA SIERADZ

INSTYTUT SZTUKI, POLSKA AKADEMIA NAUK

\title{
PRZYCZYNEK DO HISTORII PRZYJAŹNI STEFANA JAROCIŃSKIEGO I WITOLDA LUTOSŁAWSKIEGO. LISTY KOMPOZYTORA PRZECHOWYWANE W DZIALE ZBIORÓW SPECJALNYCH INSTYTUTU SZTUKI PAN (1947-196I)
}

\begin{abstract}
Tesienią 2017 r. do Działu Zbiorów Specjalnych Instytutu Sztuki PAN w Warszawie trafiło przekazane przez Hannę Jarocińską archiwum jej męża, Stefana Jarocińskiego, wybitnego znawcy muzyki francuskiej przełomu XIX i XX w. i monografisty Claude'a Debussy'ego, niemal całe zawodowe życie związanego z Instytutem Sztuki, wieloletniego szefa tutejszego Zakładu Historii Muzyki. W znacznym stopniu archiwum uporządkowane było przez jego właściciela jeszcze za życia, w Zbiorach Specjalnych materiały zostały zabezpieczone i opisane, systematycznie posegregowane w teczki i w ramach teczek w zakładki. Zawiera dokumenty dotyczące działalności naukowej, innej działalności zawodowej, kopie tekstów autorskich, dokumenty prywatne, materiały prasowe, programy koncertowe $\mathrm{i}$ in. oraz korespondencję służbową i prywatną (listy przychodzące i kopie wychodzących). Korpus ten opatrzony został numerem inwentarzowym $2 \mathrm{II} 8$ (na potrzeby niniejszej publikacji poprzedziłam go skrótem ASJ-ZS IS PAN). W teczkach gromadzących korespondencję (oznaczonych sygnaturą V-I i V-2), wśród setek (czy wręcz tysięcy) innych pism znalazło się także dwanaście listów od Witolda Lutosławskiego (teczka V-2 LI004). Ostatni pod względem chronologii, trzynasty list Lutosławskiego do przyjaciela znajduje się w jednej z trzech teczek, w których wyodrębnione zostały materiały związane tylko z kompozytorem. Oznaczone są jako ASJ-ZS IS PAN, nr inw. 2II8, II-5D (Witold Lutosławski - materiały do monografii i inne, bez numeracji kart) i podzielone na trzy grupy dokumentów: I) W. Lutosławski. Monografia i inne teksty (kopie maszynopisowe i rękopisy, notatki na fiszkach dotyczące artykułów, esejów poświęconych kompozytorowi, wypisy z publikacji innych autorów na temat kom-
\end{abstract}

I Podobnie jako osobny zbiór wyodrębnione zostały dokumenty związane z Andrzejem Panufnikiem (sygn. II-5F - Andrzej Panufnik - materiały różne). 
pozytora - Stefana Kisielewskiego, Zygmunta Mycielskiego i in., oraz różne wersje życiorysów bądź szkiców biograficznych²), 2) W. Lutosławski. Materiały różne (programy koncertowe, wycinki prasowe itp., tu też nieznany portret Lutosławskiego ołówkiem z 1959 r. podpisany inicjałami T.K.) oraz 3) Teksty autorskie. W. Lutosławski - materiały do monografii. Rękopisy nutowe3 ${ }^{3}$

Ów trzynasty list, datowany w Wiedniu na 23 IX I96I r., zasługuje na szczególną uwagę, gdyż zawiera autorefleksje oraz wyjaśnienia-podpowiedzi kompozytora dotyczące właśnie zaprezentowanych polskim słuchaczom Gier weneckich ${ }^{4}$. Stefan Jarociński już w relacji z weneckiego Biennale, gdzie miała miejsce prapremiera niekompletnych jeszcze Jeux vénitiens (bez części III), pisał, że „[z] nowej muzyki największy oddźwięk wzbudziły i najwięcej pochwał wśród muzyków zbierały Jeux vénitiens - najnowsza, nieskończona, «aleatoryczna», ale bardzo oryginalna kompozycja Lutosławskiego [oraz Fonogramy K. Pendereckiego i Wektory I R. Kayna M.S.]"s. Kilka miesięcy później, w związku z premierowym wykonaniem w Warszawie kompletnej wersji utworu, przygotował dla Ruchu Muzycznego esej zatytułowany „Indywidualność Lutosławskiego”6 . Z treści listu kompozytora wynika, że Jarociński na tę okoliczność zwrócił się do kompozytora o pewne wyjaśnienia dotyczące pro-

2 Do tytułu jednego z nich - „Witold Lutosławski” - dodana jest sporządzona ręką kompozytora notatka: „ściska Cię serdecznie / 28/XII I965”, a na odwrocie kartki dwa obszerne uzupełnienia zawierające informacje dla kompozytora ważne bądź bieżące, najwidoczniej nieznane jeszcze wówczas Jarocińskiemu: I) „Pierwszym utworem L., którego prawykonanie odbyło się za granicą, były wspomniane [przez Jarocińskiego - M.S.] «3 poematy Henri Michaux». Podobnie będzie też z następnymi utworami: premiera Kwartetu odbywa się w Sztokholmie, «Paroles tissées» na festiwalu w Aldeburgh (przy czym kompozytor sam bierze w nim udział jako dyrygent swego utworu). Fakty te pozostają w związku z coraz liczniej napływającymi z zagranicy zamówieniami na nowe kompozycje".

2) „W $1963 \mathrm{r}$. w czasie festiwalu w Zagrzebiu po raz pierwszy po dłuższej przerwie pokazuje się Lutosławski na estradzie koncertowej, tym razem jako dyrygent-współwykonawca swego utworu «3 poematy Henri Michaux». Po tym pierwszym występie dyryguje również tym samym utworem na «Warszawskiej Jesieni» w 1963 r. Przyjmuje też analogiczne propozycje na występy w Hamburgu, Kopenhadze, Monachium itd. Pedagogiczną działalność rozpoczyna Lutosławski w I962 r., prowadząc kurs kompozycji w Tanglewood (U.S.A.), po czym w 1963 r. i 1964 wykłada w Summer School of Music w Darlington (Anglia), oraz w 1964 r. w Szwedzkiej Królewskiej Akademii Muzyki w Sztokholmie".

3 Znajdują się tu przechowywane w oryginalnej kopercie opisanej przez Stefana Jarocińskiego jako „Rękopisy nutowe Witolda Lutosławskiego” autografy kompozytora: szesnaście kart papieru nutowego zawierających kompozycje (także szkice z poprawkami) z cyklu Sześć piosenek dziecinnych do stów Tuwima (1947) (Taniec, Rok i bieda, Kotek, Idzie Grześ, Rzeczka, Ptasie plotki), Dwie piosenki dziecinne do stów Tuwima (1947) (Spóźniony stowik, O Panu Tralalińskim) oraz utwory na fortepian, m.in. Trzy utwory dla mtodzieży (1953) (Czteropalcówka, Melodia, Marsz).

4 Przypomnijmy, że premierowe wykonanie (bez cz. III) utworu miało miejsce podczas weneckiego Biennale 24 IV I96I r., całość wykonana została podczas festiwalu Warszawska Jesień I6 IX I96I roku. W roku 1962 kompozycja otrzymała I Nagrodę na Międzynarodowej Trybunie Kompozytorów UNESCO.

5 Stefan Jarociński, „Międzynarodowy Festiwal Muzyki Współczesnej w Wenecji”, Ruch Muzyczny 5 (196I) nr I2, s. I6.

6 Stefan Jarociński, „Indywidualność Lutosławskiego”, Ruch Muzyczny 5 (I96I) nr 2I, s. 5-6. 
cesu twórczego, gdyż oszczędna w szczegóły nota w książce programowej ${ }^{7}$ i nawet dwukrotne doświadczenie w obcowaniu z muzyką Gier weneckich najwidoczniej nie dały podstaw do pełnej, wnikliwej i celnej analizy. W ostatnich akapitach swoich refleksji na temat Lutosławskiego - jako wybitnego homo faber współczesnej muzyki - i jego najnowszego dzieła, autor eseju odwołał się do owego wiedeńskiego listu z 23 września. Zauważmy, że wstawiony w cudzysłów cytat nie jest jedynym fragmentem zaczerpniętym z pisma kompozytora: zarówno zwięzła charakterystyka każdej z części, jak i opis zastosowanej techniki kompozytorskiej przywołane są bezpośrednio i cytowane dosłownie za kompozytorem. Znając zażyłość, jaka istniała między artystą i autorem eseju, możemy być przekonani, że wykorzystanie słów Lutosławskiego (nie zawsze jasno określone jako autoanaliza samego twórcy) nie było tu nadużyciem ze strony Jarocińskiego, a pokłosiem zaufania, jakim darzył go kompozytor, który ów list zaczyna wszak od słów: „Znajdziesz w nim [w liście - M.S.] odpowiedzi na resztę Twych pytań, wyrażone czasem skrótowo, ale chyba dosyć wyczerpująco"8.

Przyjaźń między Stefanem Jarocińskim i Witoldem Lutosławskim jest wzruszającym przykładem relacji między dwiema wybitnymi postaciami polskiej kultury II poł. XX wieku. Jarociński - jeden z głównych przedstawicieli drugiego pokolenia muzykologów polskich, autor pomnikowych prac na temat Debussy'ego - prekursorskiej w formie na tle innych monografii kompozytorskich w polskiej literaturze muzykologicznej, monumentalnej Kroniki życia, dzieta, epoki (Kraków 1972) oraz estetycznej rozprawy Debussy a impresjonizm i symbolizm (Kraków 1966), która weszła do kanonu literatury światowej w zakresie badań nad tym ikonicznym przedstawicielem impresjonizmu (a może raczej - jak to przedstawia Jarociński - symbolizmu); i Lutosławski - artysta włączony do panteonu najwybitniejszych kompozytorów stulecia. Przyjaźń między nimi, której zarania należy szukać w latach młodości, kontynuowana była przez całe życie nie tylko w sferze prywatnej, lecz także zawodowej. O relacjach tych wiemy zarówno z wypowiedzi samego Lutosławskiego, jak i Jarocińskiego; były też niejednokrotnie przypominane przez badaczy życia i dzieła kompozytora $\mathrm{z}$ jednej strony i we wspomnieniach o muzykologu z drugiej.

7 Nota o Grach weneckich w książce programowej V Festiwalu Warszawska Jesień (Warszawa 196I, s. Io), cyt. w: Witold Lutostawski. O muzyce. Pisma i wypowiedzi, opr. Zbigniew Skowron, Gdańsk 20II, s. I85.

8 Kilka miesięcy wcześniej w odniesieniu m.in. do Gier weneckich Lutosławski zanotował: „Okres, który od dłuższego już czasu przeżywam (parę lat) jest nieciekawy. Jest to okres wzmożonych poszukiwań odpowiednich dla mnie środków wyrazu. Prowadzi to nieuchronnie do stanu, w którym operuje się w dużym procencie środkami źle opanowanymi, mało znanymi. Gubi się w tym stanie pewność ręki, gubi się celność $[\ldots]$. [...] te poszukiwania postępują wolno, [...] niewiele przynoszą trwałych zdobyczy. Rezultatem tego stanu rzeczy jest fakt, że utwory tego okresu ([...] także utwór na ork. kam. z I96I [Gry weneckie]), jeśli wziąć pod uwagę ich oderwaną od wszystkiego innego wartość, stoją na pewno niżej od niektórych poprzednich moich utworów [...]. Dla mnie osobiście mają jednak wartość większą niż tamte, ponieważ prowadzą do czegoś, przygotowują coś, ułatwiają coś, co będzie o wiele bardziej moje własne [...]" (zapiski z I2 II I96I r.), zob.: Witold Lutostawski. Zapiski, opr. Zbigniew Skowron, Warszawa 2008, s. 2I. 
a)

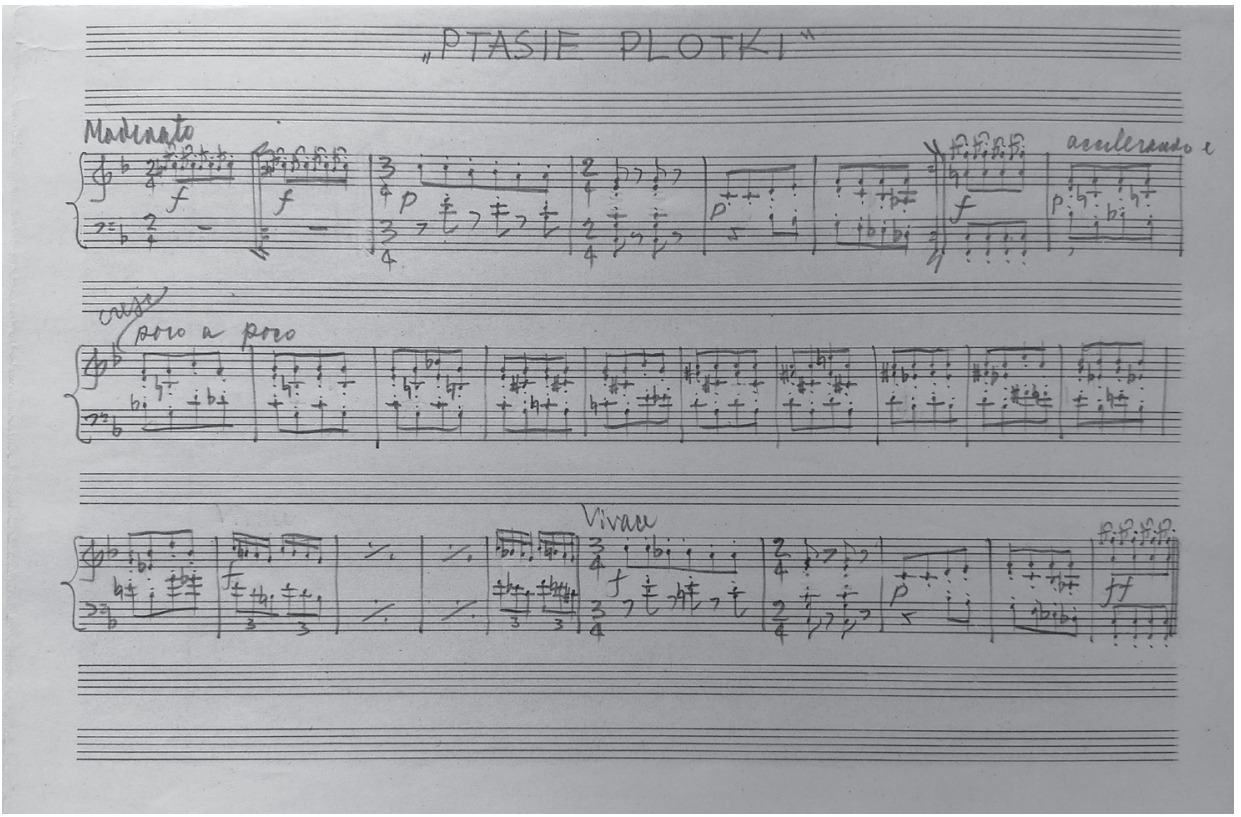

b)
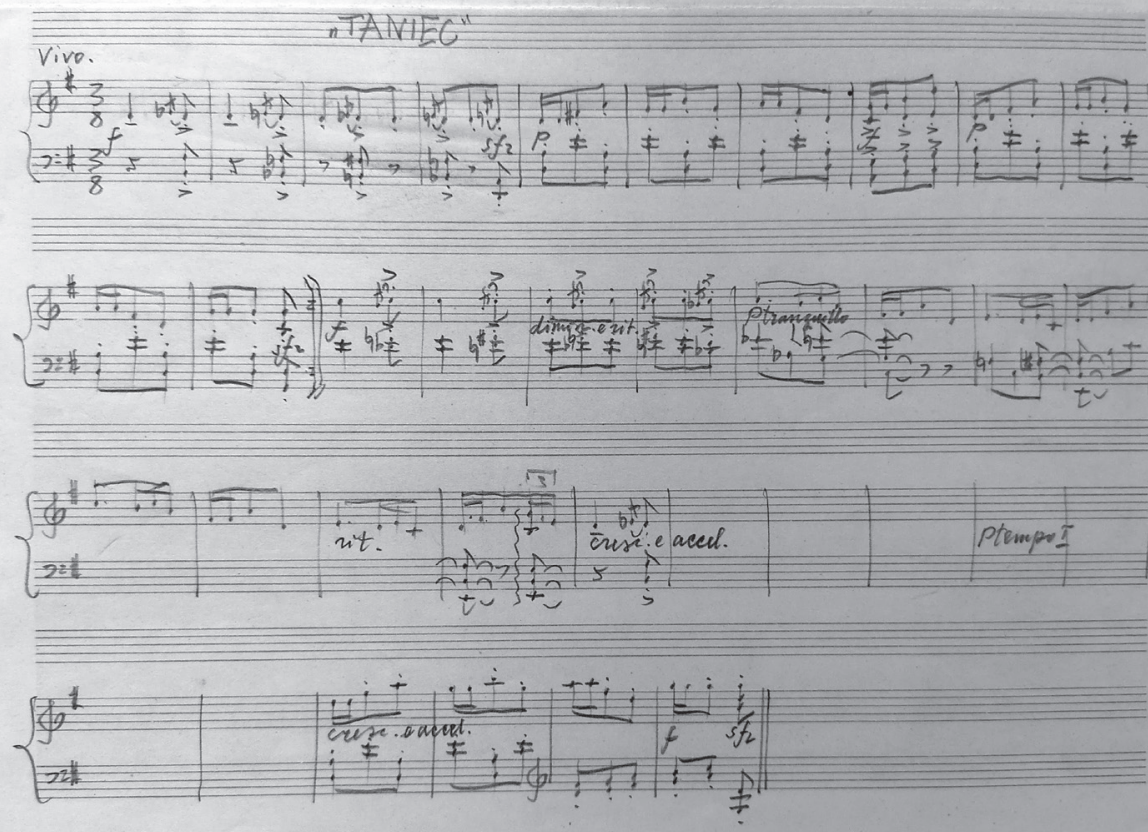

Il. Ia, b. Witold Lutosławski, Ptasie plotki i Taniec z cyklu Sześć piosenek dziecięcych do stów Tuwima, rkp. zach. w ASJ-SZ IS PAN, nr inw. 2II8, II-5D, 3) Teksty autorskie. W. Lutosławski - materiały do monografii. Rękopisy nutowe 
a)

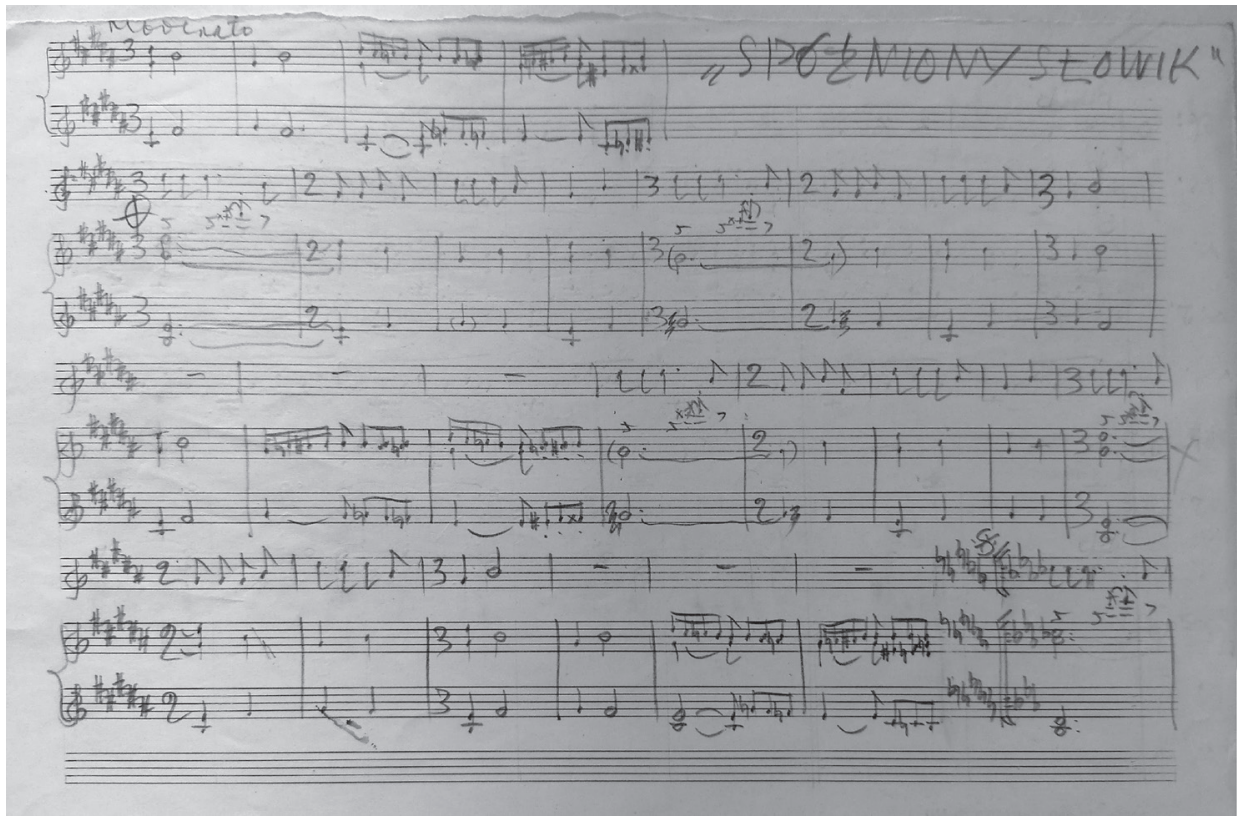

b)

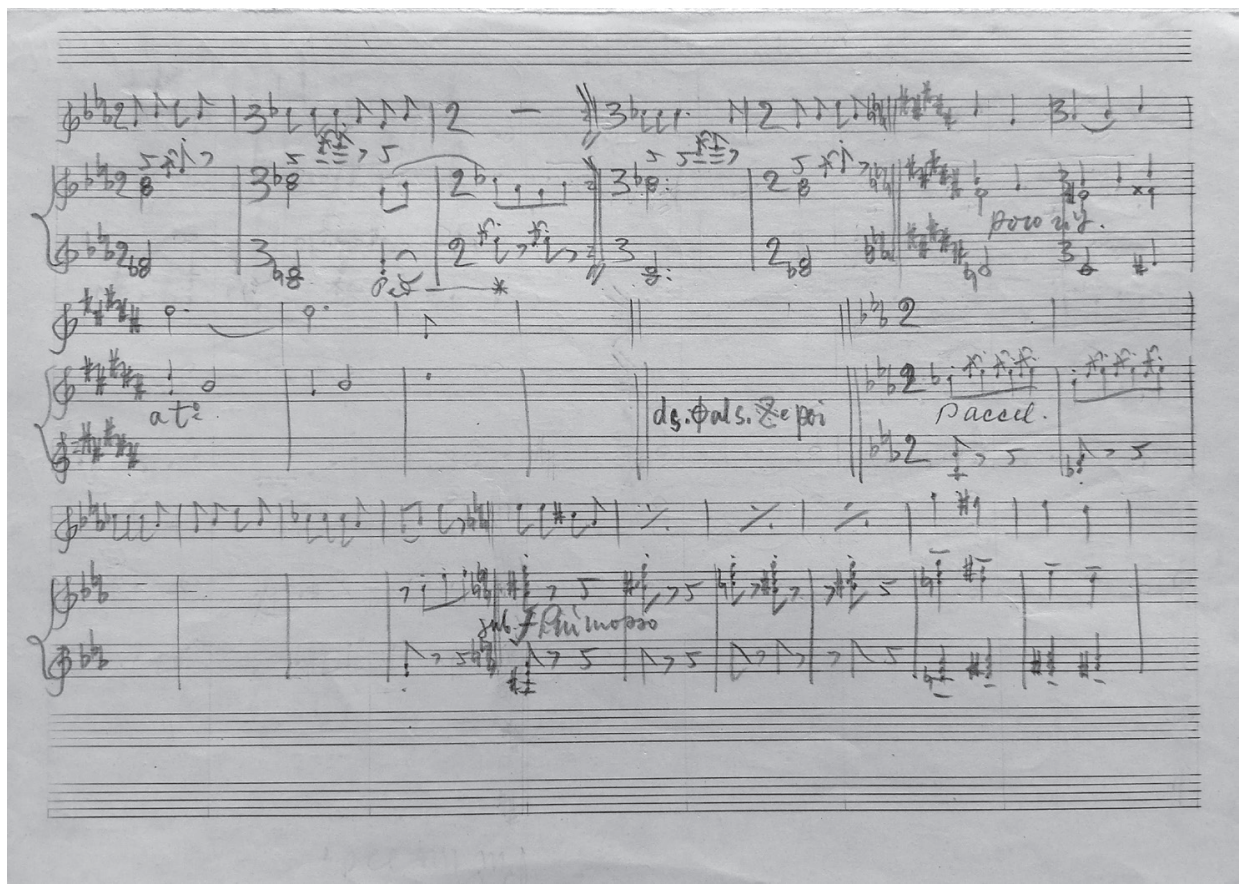

Il. 2 a, b. Witold Lutosławski, Spóźniony stowik z cyklu Dwie piosenki dziecinne do stów Tuwima, rkp. zach. w ASJ-SZ IS PAN, nr inw. 2II8, II-5D, 3) Teksty autorskie. W. Lutosławski - materiały do monografii. Rękopisy nutowe 
Znajomość, która sięgała czasów nauki w warszawskim Gimnazjum im. Stefana Batorego, przerwana została wojenną zawieruchą. Jarociński i Lutosławski, rocznik I9I2 i I9I3, po opuszczeniu szkoły wybrali różne kierunki studiów. Starszy - prawo na Uniwersytecie Warszawskim, młodszy - początkowo matematykę na tej samej uczelni, ale wkrótce poświęcił się całkowicie studiom muzycznym (fortepian i kompozycja) w warszawskim Konserwatorium, gdzie związał się ze środowiskiem młodych adeptów sztuki muzycznej - Witoldem Małcużyńskim, Heleną Warpechowską, Stefanem Kisielewskim, Grażyną Bacewiczówną i innymi. Wydaje się, że w okresie przed wojną znajomość z Jarocińskim nie miała jeszcze charakteru bardzo osobistego, choć, jak wspominał Lutosławski, przez pewien czas byli nawet kolegami z jednej klasy?.

Obaj latem 1939 r. zmobilizowani w obliczu nadchodzącej wojny, trafili na linię frontu w różnych formacjach, obaj też dostali się do niewoli, z której jednak Lutosławskiemu udało się uciec i wojnę przeżyć w Warszawie, gdzie - jak wiadomo - utrzymywał się m.in. z gry po kawiarniach w duecie z Andrzejem Panufnikiem. Z kolei Jarociński pięć i pół roku spędził w obozie jenieckim i dopiero po opuszczeniu wyzwolonego w kwietniu I945 r. Murnau i obozu przejściowego pod Limoges, latem 1945 r. dotarł do Paryża, gdzie spędził kolejne dwa lata.

Po pierwszych tygodniach pobytu w Paryżu Jarociński był gotów wracać do Polski, „[...] wbrew wszystkim pogłoskom, które się szerzą o stosunkach panujących w kraju. Z pewnością życie tam nie jest łatwe. Może jest trudniejsze, niż zazwyczaj po wojnie. Ale jest wiele przesady w tej propagandzie, która wychodzi z kół londyńskich”ı, tłumaczył w liście do Ludwika Bronarskiego, muzykologa, który ze szwajcarskiego Fryburga co najmniej od połowy I944 r. wspierał go wysyłanymi do oflagu przyjaznymi listami i książkami z zakresu historii muzyki ${ }^{\text {II }}$. Dla studiów na paryskiej Sorbonie postanowił jednak na pewien czas odłożyć swój wyjazd. Wybrał, jak sam pisał:

Sociologie et Morale na wydz[iale] filozoficznym Faculté de Lettres. [...] dlatego, że historia muzyki jest tylko w Institut d'Archeologie i to po macoszemu traktowana, natomiast muzykologii jako takiej w ogóle nie ma na Sorbonie. [...] ewentualne studia w Schola Cantorum lub Conservatoire musiałyby być obliczone co najmniej na 3 lata, wolałem zrezygnować z jednych i drugich studiów na rzecz socjologii, która mnie zawsze interesowała i to w szczególności w związku z muzykąr .

9 Zofia Owińska, Lutostawski o sobie, Gdańsk 2010, s. 69.

IO Jarociński do Bronarskiego z Paryża, 25 IX 1945 r., zach. Polska Misja Katolicka w Marly, Archiwum Rodziny Bronarskich (dalej cyt. PMK, ARB), Ludwik Bronarski (teczka nr 4), Korespondencja przychodząca (1940-VII 1948), k. 235-236.

II Więcej na temat lat w oflagu, okresu paryskiego i okresu następnego, już po powrocie do Polski, w przygotowywanym przeze mnie opracowaniu na temat ponad trzydziestu lat prywatnych i zawodowych kontaktów Stefana Jarocińskiego i Ludwika Bronarskiego.

I2 Jarociński do Bronarskiego z Paryża, 20 XII 1945 r., zach. PMK, ARB, Ludwik Bronarski (teczka nr 4) Korespondencja przychodząca (I940-VII 1948), k. 268. 
Należy tu wspomnieć, że do Paryża trafił wraz z grupą innych więźniów oflagu w Murnau - m.in. architektem Jerzym Sołtanem, malarzem i architektem Bohdanem Urbanowiczem, astronomem Włodzimierzem Zonnem. Na miejscu dość szybko nawiązał kontakt z innymi przebywającymi w mieście Polakami, m.in. muzykami z kręgu salonu Nadii Boulanger - Antonim Szałowskim, Michałem Spisakiem. Zawiązane wówczas przyjaźnie przetrwały lata: w archiwum Stefana Jarocińskiego znajduje się bogata korespondencja od małżeństwa Sołtanów, od Antoniego Szałowskiego, Włodzimierza Zonna czy od Michała Spisaka, który Jarocińskiemu i jego nowo poznanej partnerce, a już wkrótce żonie, Michalinie, stał się tak bliski, że wiosną $1948 \mathrm{r}$. został ojcem chrzestnym ich syna, Michała Marka ${ }^{13}$.

Po dwóch latach pobytu w Paryżu, w kwietniu 1947 r. Jarociński powrócił do kraju. Do wyjazdu skłaniały go i względy osobiste, i pogorszenie stanu zdrowia (mocno nadszarpniętego latami pobytu w oflagu), ale też konkretne propozycje zawodowe. Wówczas to bowiem, wiosną 1947 r., od Witolda Lutosławskiego, którego spotkał w Paryżu kilka miesięcy wcześniej, dostał list (pierwszy z szeregu kilkunastu zachowanych), w którym m.in. czytamy:

Jeśli przyjedziesz i będziesz chciał, obejmiesz posadę kierownika muzycznego „Teatru radiowego" w Warszawie. Jest to zajęcie, które mnie proponowano w swoim czasie i do dziś wakuje. [...] Ja nie przyjąłem, bo nie mogę się wiązać na stałe godziny dzienne, bo by mi to rozwalało pracę kompozytorską. Bylibyśmy stale w kontakcie, bo ja bym był Twoim „dostawcą" (Lutosławski z Warszawy, IO III I947) ${ }^{14}$.

Lutosławski już w pierwszych miesiącach po wyzwoleniu Warszawy, jeszcze przed ostatecznym zakończeniem wojny, odnalazł swoje miejsce w życiu kulturalnym kraju. Ponieważ jego życiorys jest dobrze znany, a szczególnie interesująco zrelacjonowany przez cytowanych już Danutę Gwizdalankę i Krzysztofa Meyera ${ }^{\mathrm{Is}}$, przypomnijmy

I3 Wybór listów do Michała Spisaka znany jest z edycji włączonej przez Leona Markiewicza do monografii kompozytora (Michat Spisak I9I4-1965, Dąbrowa Górnicza-Kraków 2005). W archiwum Jarocińskiego w Instytucie Sztuki PAN pełny pakiet listów wraz z innymi dokumentami związanymi ze Spisakiem zgromadzono obok teczek z korespondencją prywatną w osobnym pliku opisanym jako „Michał Spisak - korespondencja, partytury i inne teksty".

I4 Lutosławski pracował na etacie w Polskim Radiu jedynie do marca 1946 r., o czym biografowie kompozytora, Danuta Gwizdalanka i Krzysztof Meyer, piszą: „W marcu 1946 Lutosławski ustąpił ze stanowiska kierownika działu muzyki poważnej w radiu i odtąd już nigdy nie zatrudnił się jako "pracownik etatowy». Jego następcą został dyrygent Tadeusz Wilczak”, zob.: Danuta Gwizdalanka, Krzysztof Meyer, Lutostawski. Droga do dojrzatości, Kraków 2003, s. I42. Kompozytor z rozgłośnią formalnie związany był od I V I945 r., odpowiadał za dobór muzycznego tła do audycji literackich. Wkrótce zaczął też tworzyć własne, oryginalne oprawy do słuchowisk radiowych. Na ten temat zob.: Wioleta Muras, „Podążając śladami dźwiękowej wyobraźni. Muzyka Witolda Lutosławskiego w słuchowiskach Polskiego Radia”, Muzyka 6I (2016) nr 2, s. 57-84; tejże, Twórczość użytkowa Witolda Lutostawskiego w świetle jego biografi i w kontekście przemian audiosfery w XX wieku, Wrocław 2019, zob. zwł. rozdz. IV „Działalność i twórczość radiowa", s. II4-2I4.

Is Cytowaną wyżej monografię Lutostawski. Droga do dojrzatości (op. cit.) uzupełniała druga: Lutostawski. Droga do mistrzostwa (Kraków 2004). 


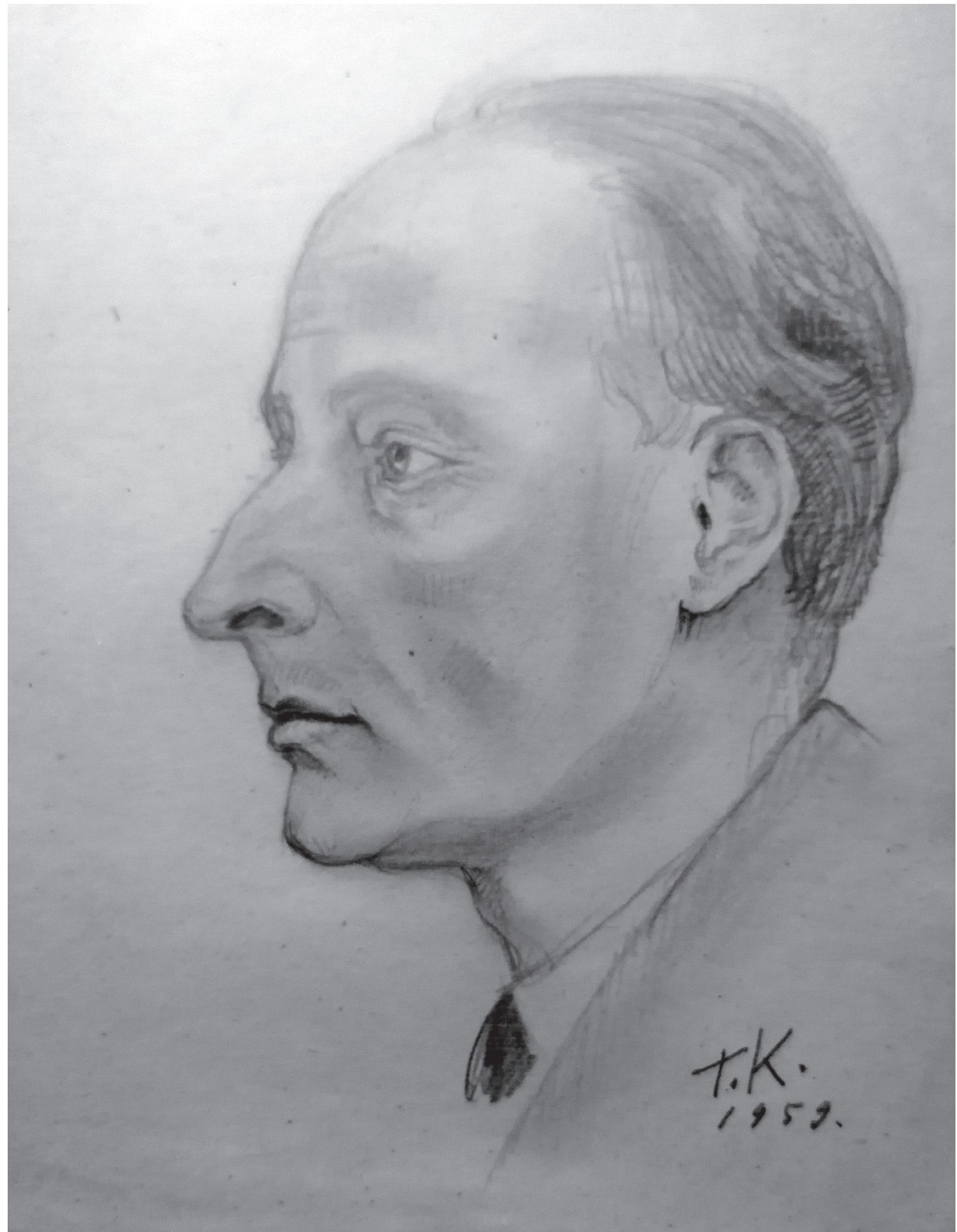

Il. 3. T.K. (?), portret Witolda Lutosławskiego, ołówek, 1959, zach. w ASJ-SZ IS PAN, nr inw. 2II8, II-5D, 2) W. Lutosławski. Materiały różne 
jedynie kilka faktów z kalendarza życia artysty, które odnoszą się do okresu obejmującego przedstawiany tu materiał.

Już w 1945 r., obok pracy w Polskim Radiu, kompozytor objął stanowisko sekretarza i skarbnika w nowo utworzonym Związku Kompozytorów Polskich. Jego utwory były wykonywane na pierwszych organizowanych w kraju koncertach, m.in. na Festiwalu Polskiej Muzyki Współczesnej, który towarzyszył pierwszemu zjazdowi ZKP odbywającemu się na przełomie sierpnia i września 1945 roku. Szczęśliwie znalazł się w grupie młodych kompozytorów, którzy otrzymywali ministerialne wsparcie finansowe, wkrótce zaczął też otrzymywać z ministerstwa kultury zamówienia na swą twórczość.

W grudniu 1946 r. w Paryżu odbył się koncert „polski” w ramach „narodowych” koncertów państw-członków UNESCO; w programie wykonywanym przez Orchestre National de la Radiodiffusion Française pod dyrekcją Grzegorza Fitelberga znalazły się m.in. Wariacje symfoniczne Lutosławskiego. Kompozytorowi udało się przyjechać na to wydarzenie i w Paryżu spędził ostatecznie trzy następne miesiące, „zwiedzając miasto, bywając na koncertach, zawierając znajomości. Poznał Nadię Boulanger i regularnie uczęszczał na środowe spotkania w jej domu”' ${ }^{\text {I6 }}$. Gwizdalanka i Meyer przywołują nazwiska kilku osób, które wówczas spotkał: Michała Spisaka, Henriego Barrauda, Antoniego Szałowskiego, Witolda Małcużyńskiego. Nie wspominają natomiast Stefana Jarocińskiego, tymczasem przypomniana i odnowiona w tych szczególnych okolicznościach znajomość z czasów szkolnych szybko przerodziła się w prawdziwą i trwałą przyjaźń. Dziś wiemy, że koledzy spędzali ze sobą wiele czasu, co Lutosławski wspominał m.in. tak:

Spotkaliśmy się ponownie [licząc od lat gimnazjalnych - M.S.] po wojnie, w 1946 roku, kiedy przyjechałem po raz pierwszy do Paryża. Stefan przebywał tam po wyjściu z oflagu ze swoją ówczesną żoną. Widywaliśmy się wtedy prawie co dzień, a później już także po jego przyjeździe do Warszawy, gdzie spotykaliśmy się regularnie ${ }^{17}$.

Miejsce z tym czasem związane - paryskie Battignoles - kompozytor obdarzył szczególnym sentymentem i uważał za wspólną „własność”: „Dziś, kiedy piszę do Ciebie te parę słów - ożywają mi w pamięci wszystkie przyjemne momenty pobytu w Paryżu, a muszę Ci powiedzieć, że wiele, jeśli nie większość, związane jest z Twoją osobą. Szalenie się cieszę z odnowienia naszej znajomości - a właściwie - jeśli pozwolisz tak to nazwać - przyjaźni” - pisał Lutosławski do Jarocińskiego Io III I947 r., tuż po powrocie do kraju. A z kolei wrażenia z Paryża, który odwiedził podczas pobytu we Francji dwa lata później, opisał tak: „[...] jakoś niespecjalnie się rozkoszuję tym pobytem. «Nasza» dzielnica - Battignoles - opustoszała i martwa od czasu, jak jej nie zamieszkujesz. Bardzo mi chodzą po głowie nasze rozmowy i spotkania sprzed 
2 lat, wieczór wigilijny, spacer do St.-Germain-en-Laye etc.” (Lutosławski z Paryża, 3 XI I948 r.).

W Polsce obaj mieli ścisły kontakt i zawodowy, i prywatny, choć utrudniony faktem, że Jarociński przez kolejnych dwadzieścia lat mieszkał nie w stolicy, lecz w podwarszawskim Milanówku. Lutosławski był - jak sam to ujął - „dostawcą” materiału muzycznego dla Jarocińskiego organizującego prace działu teatralnego i dosyłał mu szczegóły planowanych realizacji (obsada, minutaż, zob. list z Warszawy, 6 X 1947 r.), choć zwracał się też w czysto osobistych sprawach (jak w kwestiach honorarium - list z Ustki latem 1947 r., czy w krótkiej relacji z żeglowania po Wiśle - list z Warszawy, 30 VIII i955 r.). Pisał też o swych wrażeniach z koncertów, w tym z wykonania Koncertu na dwa fortepiany Michała Spisaka wiosną 1948 r. w Krakowie: „Jest to z pewnością kawał dobrej muzyki, ale powstrzymuję się z jakimiś bardziej stanowczymi sądami, to za mało raz usłyszeć” (z Katowic, 23 III I948 r.).

O samym Spisaku wspomina zresztą niejednokrotnie i serdecznie, z czego widać, jak ścisły był to krąg znajomych ${ }^{18}$. W wątek tej „potrójnej” przyjaźni wpisuje się też krótka, ale szczególna w wyrazie emocjonalnym, kartka Lutosławskiego z I3 XII I948 r., której enigmatyczna treść mówiąca o liście „bardzo przejmującym, który zapadł mi [Lutosławskiemu - M.S.] głęboko w świadomości”, do czytania „dla otuchy” i „w chwilach ciężkich” (podkreśl. M.S.), zastanawia. Ma jednak - jak się okazuje - swoje znane skądinąd, cytowane już w literaturze źródło. Otóż w przywoływanej monografii kompozytora Gwizdalanka i Meyer cytują słowa z zachowanego w Paul Sacher Stiftung listu Jarocińskiego do przebywającego późną jesienią I948 r. w Paryżu Lutosławskiego. Czytamy m.in.:

[...] Gdy powiedzmy z jakichś względów Michał [Spisak] przestałby nagle pewnego dnia komponować, to fakt ten, chociaż przykry - bo cenię jego muzykę - nie miałby zasadniczego wpływu na mój stosunek do niego. Gdybyś natomiast Ty przestał pisać muzykę, odczułbym to jako osobistą klęskę życiową. [...] Kiedy się obcuje z Tobą, doznaje się uczucia pokory nie tylko w stosunku do Ciebie jako artysty, ale i w stosunku do Ciebie jako człowieka. Te dwie strony natury mogą iść z sobą w parze tylko w osobniku genialnym i to pod warunkiem, że są z sobą w równowadze. [...] choćbyśs to uznał za moje śmieszne uproszczenie, Twoja klęska byłaby także moją klęskąri .

Twórczość Lutosławskiego inspirowała Jarocińskiego na tyle, że dość szybko stała się obiektem jego analiz i studiów. Przypomnijmy, że Jarociński przede wszystkim

I8 Potwierdza to też wiele słów pisywanych przez Spisaka do Jarocińskiego: „Witek był tylko 2 dni w Paryżu. Bardzo się ucieszyłem, gdy zobaczyłem jego gębę. Po jego powrocie z południa obiecuję sobie dużo mile spędzonych z nim chwil” (Spisak z Paryża, I7 IX I948 r.), „Witold wyjeżdża 3-go. Widujemy się bardzo często - mam dla niego kupę przyjaźni i uznania” (Spisak z Paryża, 26 XI 1948 r.), „Ciekaw jestem, czy Witold przyjedzie na wykonanie swej Symfonii w Paryżu. [...] Bardzo bym się cieszył, gdyby mu się udało przyjechać” (Spisak z Paryża, 24 I 1949 r.), wielokrotnie prosił całować „Witka i Danusię”; cyt. za: L. Markiewicz, Michat Spisak, s. 223, 228, 233.

I9 Cyt. za: D. Gwizdalanka, K. Meyer, Lutostawski. Droga do dojrzatości, s. I84-185. 
pisał, a etat w Polskim Radiu traktował jako bezpieczne źródło utrzymania. Pierwsze jego teksty, przysyłane jeszcze z Paryża, publikowane były już w roku I946 na łamach Ruchu Muzycznego. Po powrocie do Polski pisywał do Twórczości i Kuźnicy, a od początku roku 1952 stał się członkiem redakcji i szefem działu muzycznego nowo otwartego tygodnika Przeglad Kulturalny, gdzie zamieszczał zarówno felietony, jak i obszerne eseje na temat muzyki współczesnej i jej przedstawicieli. To właśnie sylwetkę Witolda Lutosławskiego zaproponował na inaugurację swojej rubryki „Sylwetki twórców”"2o. I tak na przykład, komentując utarty wówczas pogląd o wpływie Szymanowskiego na przed- i okupacyjną twórczość młodego kompozytora, stwierdzał:

Był to, wydaje mi się, pogląd najzupełniej fałszywy i oparty na nieporozumieniu [...] wyrządzając oczywistą krzywdę kompozytorowi. Lutosławski nie chciał być naśladowcą ani Szymanowskiego, ani kogokolwiek. Pragnął wykuć swój własny język muzyczny - oto cały sens tych doświadczeń (mowa o wspomnianych wyżej utworach na instrumenty dęte), które on sam uważał za „laboratoryjne”, a których celowość wykażą późniejsze jego kompozycje.

Nie uchronił się przed oczekiwaną wówczas od publicystów narracją, choć między wierszami czytamy po prostu o bogactwie środków kompozytorskich, jakimi posługiwał się kompozytor:

Lutosławski nigdy nie zamierzał, ani też nie zamierza zrezygnować z posługiwania się zdobyczami techniczno-formalnymi ostatniego półwiecza [...]. [...] skoro procesu rozwojowego muzyki cofnąć niepodobna, trzeba pomyśleć o takim użyciu istniejącego zasobu środków artystycznego działania, które by wbrew trudnościom zasypało wykopaną przez ustrój burżuazyjny przepaść między twórcą i odbiorcą, przywróciło ich wzajemne zrozumienie, nadało sztuce ludzkie oblicze.

I podsumowuje:

Od śmierci Szymanowskiego niewielu znalazło by się w Polsce tej miary kompozytorów, co Lutosławski. Wysoka kultura [...] wrażliwość estetyczna, rzadko spotykane mistrzostwo techniczne, $[\ldots]$ głębokie poczucie odpowiedzialności [...] oto cechy tej wybitnej indywidualności artystycznej, od której mamy prawo oczekiwać dzieł godnych wielkiej epoki, w jakiej żyjemy ${ }^{21}$.

$\mathrm{Na}$ łamach Przegladu Kulturalnego powrócił do Lutosławskiego w roku 1954, po premierowym wykonaniu Koncertu na orkiestrę, o którym kilka lat wcześniej, w sylwestrowy wieczór $1950 \mathrm{r}$. kompozytor pisał do przyjaciela: „pracuję pełną parą i nie ma dnia, żeby coś nie przybyło do mojego "Koncertu na orkiestrę». Miesiąc temu skończyłem I cz., od tego czasu napisałem kawał finału i zarysowałem jego całość. Środkowe części pozostawiam na później, bo I cz. i finał to filary całej budowli i chcę je mieć najpierw" (Lutosławski z Warszawy, 3I XII I950 r.). Po kilku latach Jarociński mógł tę pracę podsumować:

20 Stefan Jarociński, „Witold Lutosławski”, Przeglad Kulturalny I (I952) nr II, s. 3.

2I Ibid. 
Do skromnej liczby tych pod szczęśliwą gwiazdą zrodzonych dzieł, którym powodzenie sprzyjało od początku, i na nas przyszła kolej wpisać jedno - Koncert na orkiestrę Witolda Lutosławskiego. Publiczność, która [...] zamanifestowała tak gorąco swoje uznanie dla dzieła, nie pomyliła się w ocenie miejsca, jakie ono zajęło od razu, wstępnym bojem w hierarchii osiągnięć naszej współczesnej muzyki - miejsca najwyższego. Czekaliśmy na to arcydzieło od lat. [...] Byli tacy, którzy utrzymywali, że Lutosławski to wielki kompozytor od małych form i gotowi mu byli jak Ravelowi ofiarować tytuł „zegarmistrza”. [...] Aż wreszcie przyszedł Koncert i obalił ostatecznie fałszywe mniemania ${ }^{22}$.

Co oczywiste, wspominał Lutosławskiego w opublikowanym w I953 r. także na łamach Przegladu Kulturalnego dwugłosie z Michałem Bristigerem, z którym dyskutował sprawy polskiego powojennego dorobku muzycznego, w tym m.in. artystyczne dokonania Grażyny Bacewiczówny, Jana Krenza, Andrzeja Panufnika, Tadeusza Bairda, Zygmunta Mycielskiego, Piotra Perkowskiego; kilka lat później, znów sam, omawiał nowe kompozycje twórcy Matej suity ${ }^{23}$. Nie ograniczał się do łamów Przeglądu - pisywał do Anteny, Ruchu Muzycznego i periodyków zagranicznych ${ }^{24}$. Należy też pamiętać, że w tym samym czasie nawiązał już współpracę ze środowiskiem stricte akademickim: rozpoczął pracę w Państwowym Instytucie Sztuki (późniejszym Instytucie Sztuki PAN), gdzie także kierował swoje artykuły i rozprawy, nie tylko zresztą z zakresu muzyki współczesnej. Podejmował wówczas decyzje co do tematów prac naukowych, które w kolejnych latach wypełniały mu czas już jako muzykologa. Z jednej strony badania nad historią polskiej krytyki muzycznej, które zaowocowały m.in. artykułami o Maurycym Mochnackim i tomem antologii ${ }^{25}$, z drugiej estetyczne rozważania na temat muzyki przełomu XIX i XX w. ${ }^{26}$. Ale wśród licznych publikacji zamieszczonych na łamach instytutowych czasopism - Muzyki (zarówno miesięcznika, jak i kwartalnika), Studiów Muzykologicznych, Materiatów do Studiów i Dyskusji z Zakresu Teorii i Historii Sztuki, Krytyki Artystycznej oraz Metodologii Badań nad Sztuką - znalazła się też jego analiza czy też „recenzja” cyklu miniatur fortepianowych Lutosławskiego. O Bukolikach pisał tak:

22 Stefan Jarociński, „Wielka muzyka”, Przeglad Kulturalny 3 (1954) nr 49, s. 2.

23 Stefan Jarociński, Michał Bristiger, „Obrachunki muzyczne. Dialog o zadawnionych i aktualnych sprawach twórczości”, Przegląd Kulturalny 2 (1953) nr II, s. 3; Stefan Jarociński, „Nowa muzyka Lutosławskiego", Przeglad Kulturalny 7 (1958) nr 22, s. 7.

24 Bibliografia prac Stefana Jarocińskiego opublikowana została w zeszycie specjalnym kwartalnika $\mathrm{Mu}$ zyka 58 (2013) $\mathrm{nr}$ 3, na który złożyły się ponadto teksty wystąpień wygłoszonych podczas konferencji „La Pologne en France - La France en Pologne” zorganizowanej w stulecie jego urodzin (do zeszytu dołączona została też płyta z fragmentami przygotowywanych przez Elżbietę Markowską audycji radiowych z cyklu „Fonoteka XX wieku” - wypowiedzi Jarocińskiego na temat muzyki francuskiej). Już dziś można stwierdzić, że dzięki zachowanym przez samego badacza wycinkom prasowym można będzie uzupełnić ją o kolejne tytuły artykułów i esejów.

25 M.in.: „Maurycy Mochnacki jako krytyk muzyczny”, Studia Muzykologiczne 3 (1954), s. 389-520; Antologia polskiej krytyki muzycznej XIX i XX wieku (do roku 1939), Kraków I955 (= Z Prac Państwowego Instytutu Sztuki).

26 Stefan Jarociński, „Główne tendencje estetyczne w muzyce XX wieku”, Muzyka I (1956) nr 3, s. 3-22. 
W założeniu swoim miały to być utwory przeznaczone dla pianistów niezaawansowanych technicznie, ale stawiające im za to wysokie wymagania, jeśli chodzi o muzykalność. [...] Jednakże w toku realizacji te pedagogiczne zrazu założenia odsunąć musiał kompozytor na plan dalszy, widocznie pod naporem wzmagającej się w nim potrzeby pogłębienia emocjonalnego swych „robótek”, ponieważ ostatecznie otrzymaliśmy utwory, które dzięki walorom swej treści wybiegają daleko poza granice dydaktyki, i w których język łatwy technicznie nabrał cech li tylko konwencji artystycznej ${ }^{27}$.

W drugiej połowie lat pięćdziesiątych planował przygotować na zamówienie PWM „małą monografijkę o Lutosławskim” ${ }^{28}$, jednak publikacja ukazała się dopiero dziesięć lat później i miała nieco inny od pierwotnie zamierzonego charakter: niewielki, dziesięciostronicowy esej biograficzny oraz zebrana, aktualna na ten moment dokumentacja (spis kompozycji, spis artykułów, odczytów i wypowiedzi, bibliografia oraz liczne fotografie) były uzupełnieniem dla wybranych tekstów Lutosławskiego (głosy w dyskusji, fragmenty wywiadów, wykłady, wystąpienia radiowe i in.) ${ }^{29}$.

Jarociński doceniał też starania innych muzykologów w propagowaniu dzieła i sylwetki kompozytora, czemu dał wyraz w recenzji z Rozmów z Witoldem Lutostawskim Tadeusza Kaczyńskiego. Pozostawiając na boku relację z zawartości książki, przypomnijmy, w jaki sposób ocenił sam jej koncept:

Już sama możność obcowania z myślą postaci tak niepowszedniej, jak Lutosławski, dawała autorowi Rozmów do ręki atut ich atrakcyjności. Że wyzyskał go w stopniu, na jaki go było stać, nawiązując ze swym bohaterem żywy dialog, dzięki któremu wzbogacił naszą wiedzę o kompozytorze materiałem uzyskanym z pierwszej ręki, a zatem mającym wartość źródłową - zasługa to niewątpliwa T. Kaczyńskiego ${ }^{30}$.

Liczne publikacje i składane w nich wielokrotnie deklaracje uznania dla maestrii i twórczości Lutosławskiego nie były ograniczone jedynie zawodowymi zainteresowaniami Jarocińskiego, lecz wynikały wprost z obserwacji kompozytora w sytuacjach nieformalnych i podczas prywatnych spotkań, jakie towarzyszyły ich relacjom aż do śmierci autora Orfeusza na rozdrożu. W opublikowanych obszernych fragmentach rozmowy z Witoldem Lutosławskim, którą po koncercie - zorganizowanym 22 IV 198I r. w Muzeum Narodowym, a poświęconym pamięci Stefana Jarocińskiego przeprowadziła Elżbieta Markowska, czytamy m.in.:

27 Stefan Jarociński, „Nowe utwory fortepianowe Lutosławskiego”, Muzyka 4 (1953) nr 9-Io, s. 7I-76.

28 Jarociński do Bronarskiego z Milanówka, 23 I 1958 r., zach. PMK, ARB, Korespondencja Bronarskich (teczka nr 5), Korespondencja przychodząca (I958-196I), k. II.

29 Witold Lutostawski. Materiaty do monografii, zestawił Stefan Jarociński, Kraków 1967. W podpisanej w lutym I962 r. umowie z PWM zobowiązał się oddać do druku w terminie do 30 IV I962 r. już nie monografię, lecz „esej o W. Lutosławskim do wydawnictwa albumowego” (podkr. M.S.), zob.: ASJ-ZS IS PAN, nr inw. 2II8, teczka I-2 Materiały i dokumenty działalności zawodowej. Umowy wydawnicze i inne (bez numeracji kart). Bogata korespondencja na temat tej publikacji także w teczce V-I Korespondencja służbowa. PWM. 1946-1966, passim.

30 Stefan Jarociński, „Tadeusz Kaczyński: Rozmowy z Witoldem Lutostawskim. Kraków 1972 PWM”, Muzyka I9 (1974) nr 2, s. 75-79, cyt. s. 79. 
Ze Stefanem Jarocińskim łączyły mnie więzy bardzo ścisłej, gorącej przyjaźni.

[...] Muszę powiedzieć, że to, co mówił, i to, w jaki sposób mówił oraz reagował na moje utwory usłyszane po raz pierwszy, było dla mnie sprawą wielkiej wagi. [...] Z pewnością łączyły nas także wspólne zamiłowania i gusty muzyczne.

Jeżeli chodzi [...] o twórczość Jarocińskiego, a specjalnie o tę, która związana była z Debussym, muszę powiedzieć, że byłem również bardzo gorliwym jej czytelnikiem. Entuzjazmowałem się jego Kronika życia i twórczości Debussýego, nad którą pracował szereg lat, a której poszczególne rozdziały przynosił w maszynopisie do nas do domu i często nawet sam je czytał. Muszę powiedzieć, że kolejne fragmenty tej książki były tak ekscytujące, że nie mogliśmy się z żoną doczekać, kiedy Stefan przyniesie następny rozdział i znowu go nam odczyta ${ }^{31}$.

Jest to szczególny rodzaj zażyłości, kiedy z osobami bliskimi dzielimy się swym opus vitae jeszcze przed udostępnieniem go szerokiemu odbiorcy. W przedstawionych poniżej listach możemy prześledzić, jak przyjaźń między dwiema wybitnymi postaciami polskiej kultury II poł. XX w. rozwijała się w pierwszych latach po ustaniu pożogi wojennej, wraz z odnowieniem ich młodzieńczej znajomości.

Kiedy Stefan Jarociński na początku lat pięćdziesiątych rozpoczynał drogę literacką, swą pierwszą publikację poprzedził dedykacją: „Witoldowi Lutosławskiemu tę pierwszą swoją książkę poświęca autor" ${ }^{32}$, zaś Witold Lutosławski po śmierci przyjaciela poświęcił jego pamięci Grave - monografia Mozarta i muzyczne pro memoriam, dwa utwory, które, jak symboliczną klamrą, spięły lata ich przyjaźni33.

Witold Lutosławski, [fragment rozmowy radiowej z Elżbietą Markowską], cyt. za: Lutosławski 19I3-20I3, koncepcja albumu, wybór materiałów i opr. Elżbieta Markowska, Warszawa 20I3, s. I44. Podobne pełne uznania dla monografistyki Jarocińskiego wspomnienia przekazał także Zofii Owińskiej: „Stefan poświęcił szereg lat Debussy'emu. Napisał o nim dwie książki, wielka szkoda, że tylko jedna z nich [Debussy a impresjonizm i symbolizm] wyszła po francusku, bo i ta druga [Debussy. Kronika życia, dzieta, epoki] jest fascynująca", zob.: Z. Owińska, Lutostawski o sobie, s. 68. Jak się okazuje, Lutosławski czynił pewne starania, by zarekomendować na zagranicznym rynku tę wybitną pracę. Od Lutosławskiego o Kronice usłyszał m.in. szef londyńskiego wydawnictwa J. \& W. Chester, Robin Boyle, z którym kompozytor pozostawał w ścisłych kontaktach „businessowych” i prywatnych. W archiwum Stefana Jarocińskiego znajduje się szereg listów z Londynu poruszających kwestię ewentualnej współpracy wydawnictwa z monografistą Debussy'ego. W pierwszym z nich czytamy: „Dear Professor Jarociński, Debussy - His Life and Epoch / By a strange combination of circumstances, I have recently heard from two different sources about your magnificent book [podkr. M.S.] - the first being Witold Lutosławski [...]. I am writing to say that I would be most interested in publishing an English version of this book and I hope that the idea appeals to you", Boyle do Jarocińskiego z Londynu, I XII 1975 r., zach. ASJ-ZS IS PAN, nr inw. 2II8, teczka V-I Korespondencja służbowa. Różne instytucje i osoby I946-1980, k. 73. Do wydania nie doszło, nie miejsce tu jednak na przedstawianie szczegółów tego niezrealizowanego projektu (dodam jedynie, że drugą osobą, która wspomniała Boylowi o dokonaniach Jarocińskiego, był Richard Langham Smith, wówczas wykładowca muzyki na Uniwersytecie Lancaster, który polskiego badacza spotkał w Centre de documentation Claude Debussy w Paryżu).

32 Stefan Jarociński, Mozart, Kraków 1954 (= Małe Monografie Muzyczne 3), s. [5]. Dedykacja była integralnym elementem publikacji i pojawiła się we wszystkich sześciu wydaniach Mozarta.

33 Przypomnijmy tu, że w kontekście badawczych pasji Jarocińskiego dodatkowo poruszającym faktem jest otwarcie Grave czterodźwiękową frazą Debussy’owego „motywu lasu”. Sam kompozytor mówił o tym niejednokrotnie: „Uważałem [...] za właściwe umieścić na początku mego utworu cztery pierw- 
Z dość dużą dozą pewności można przyjąć, że znajdujące się w Archiwum Stefana Jarocińskiego listy Witolda Lutosławskiego są jedynymi zachowanymi pismami kierowanymi do niego przez kompozytora; niniejszy tekst ma na celu przede wszystkim zaprezentowanie tych źródeł. Kwestią otwartą pozostaje ustalenie, gdzie i w jakim zakresie napotkać można korespondencję odwrotną - naturalnym kierunkiem zdają się tu być zasoby Paul Sacher Stiftung. Na pewno jednak już sama lektura przedstawionych poniżej pism, skonfrontowana dodatkowo z innymi archiwaliami (m.in. ze znaną mi już wcześniej wojenną i powojenną korespondencją z Ludwikiem Bronarskim ${ }^{34}$ ), pozwoliła na dodanie bądź wyjaśnienie kilku epizodów z życia obu przyjaciół, a zebrane w teczkach archiwum Stefana Jarocińskiego materiały związane w różny sposób z kompozytorem mogą stanowić kolejne ciekawe źródła dla badaczy życia i dzieła twórcy $M i$-parti.

sze nuty z Peleasa i Melizandy, które są punktem wyjścia dla melodyki partii wiolonczelowej. Utwór ma formę metamorfoz, w których - podobnie, jak w mej Muzyce żałobnej - wartości rytmiczne ulegają stopniowemu rozdrabnianiu, co stwarza iluzję coraz szybszego tempa. Przed samym zakończeniem utworu powracają znów cztery nuty z Peleasa [i Melizandy]" (Witold Lutostawski. Baza wiedzy, http:// www.lutoslawski.org.pl/pl/composition,67.html, dostęp I7 VI 2020), „Grave to mój jedyny utwór, w którym znajduje się cytat z dzieła innego kompozytora - pierwsze nuty to jest początek Peleasa i Melizandy Debussy'ego" (zob.: Z. Owińska, Lutostawski o sobie, s. 68).

34 Na listy Stefana Jarocińskiego do Ludwika Bronarskiego natrafiłam podczas kwerendy w Polskiej Misji Katolickiej w Marly, gdzie złożone zostało Archiwum Rodziny Bronarskich. Zob. też przyp. II. 


\section{ANEKS \\ LISTY WITOLDA LUTOSŁAWSKIEGO DO STEFANA JAROCIŃSKIEGO Z LAT $1947^{-1961^{35}}$}

ASJ-ZS IS PAN, nr inw. 2II8, teczka V-2 L-Ł, k. 980-98I

Warszawa, IO III I947

Kochany Stefanie!-

Już od dawna - właściwie od przyjazdu - chcę napisać do Ciebie, ale obskoczyły mnie od razu tysiące kłopotów i zajęć, odsuwając z dnia na dzień chwilę swobodniejszej myśli.

Dziś, kiedy piszę do Ciebie te parę słów - ożywają mi w pamięci wszystkie przyjemne momenty pobytu w Paryżu, a muszę Ci powiedzieć, że wiele, jeśli nie większość związane jest z Twoją osobą. Szalenie się cieszę z odnowienia naszej znajomości - a właściwie - jeśli pozwolisz tak to nazwać - przyjaźni. Mam nadzieję, że niedługo już zobaczymy się w Warszawie. Czy dostałeś wiadomość od Urbanowicza? Rozmawiałem z nim, powiedział mi, że wysyła odpowiednie listy do Ciebie i do ambasadora w Paryżu, co powinno być ułatwieniem w Twym powrocie.

Jeśli przyjedziesz i będziesz chciał, obejmiesz posadę kierownika muzycznego „Teatru radiowego" w Warszawie. Jest to zajęcie, które mnie proponowano w swoim czasie i do dziś wakuje. Pochłania po parę godzin dziennie. Stosunki b[ardzo] sympatyczne, nie ma żadnych niewygodnych rygorów, gaża do omówienia, ale myślę, że ze 20000 najmniej, za co można wyżyć. Ja nie przyjąłem, bo nie mogę się wiązać na stałe godziny dzienne, bo by mi to rozwalało pracę kompozytorską. Bylibyśmy stale w kontakcie, bo ja bym był Twoim „dostawcą”. Miałbym również możność wprowadzić Cię we wszystko. Na wszelki wypadek trzymam to stanowisko dla Ciebie. Gdybyś nie reflektował - napisz mi.

Ja tu sporo pracuję nad symfonią, której właśnie kończę III cz., na jesień będzie całośćc ${ }^{6}$ !

Jak Twoja encyklopedia?

Przesyłam wiele serdeczności, pięknie kłaniam się p. Lilli ${ }^{37}$

Witold Lutosławski

PS. Perfumy oddam p. Z. Jarocińskiej ${ }^{38}$, która zgłosiła się po nie sama.

35 Za wgląd do stanowiących zaczyn dla niniejszego komunikatu listów Ludwika Bronarskiego do Stefana Jarocińskiego jeszcze przed przekazaniem ich do Działu Zbiorów Specjalnych Instytutu Sztuki PAN oraz życzliwe potraktowanie moich planów badawczych dziękuję bardzo Pani Hannie Jarocińskiej. Za udzielenie zgody na opublikowanie listów Witolda Lutosławskiego jestem wdzięczna Panu Marcinowi Bogusławskiemu. Za pomoc i dodatkowe informacje dotyczące archiwum Jarocińskiego dziękuję Pani Krystynie Kruczyńskiej z Działu Zbiorów Specjalnych IS PAN.

36 Neoklasyczna w stylu I Symfonia powstawała w l. 194I-47. Składa się z czterech części: I. Allegro giusto, 2. Poco adagio, 3. Allegretto misterioso, 4. Allegro vivace. Jej premierowe wykonanie (o czym też niżej) miało miejsce I IV I948 r. w Katowicach, grała WOSPR pod dyrekcją Grzegorza Fitelberga, a transmisja radiowa odbierana była w Polsce i Czechosłowacji.

37 Michalina Lilla z d. Nawrocka, w Paryżu, gdzie poznał ją Jarociński, studiowała na Sorbonie filologię romańską.

38 Zofia Jarocińska z d. Tosio. 
ASJ-ZS IS PAN, nr inw. 2II8, teczka V-2 L-Ł, k. 982

Ustka, [lato] 1947

Kochany Stefanie!-

Wybacz mi, że siedząc tu i wygrzewając się na słońcu, ośmielam się zanudzać Cię mymi sprawami, ale mam nadzieję, że nie uznasz tego za wielką bezczelność z mej strony i przyjdziesz mi z pomocą. Otóż prosiłbym Cię o odebranie mej pensji w wydz[iale] teatralnym albo literackim [Polskiego Radia] i wysłanie z niej sumy 5000 zł. przekazem pocztowym pod adr.: Zofia Szemplińska, Warszawa, Zwycięzców 30 m. Io, reszty zaś (po potrąceniu wszelkich kosztów) przekazem telegraficznym do mnie pod adr[es] Ustka pow. Słupsk, Darłowska II. Skoro już tu jestem, chcę urwać jeszcze parę dni sierpnia, tak że przysłana forsa zapewni powrót. Tu rzeczywiście odpoczywa się wspaniale. Czuję, że odrabiam te braki, jakie wszystkim sprawiły lata wojny, jest to pierwszy prawdziwy urlop po 7 latach. Niezupełnie przerwa na pracę, piszę i szkicuję to i owo, niedługo brak intensywniejszej pracy zacznie mi może doskwierać. Jest to również uczucie od dawna zapomniane.

Jeszcze raz przepraszam Cię serdecznie za moją śmiałość. Ściskam Cię, Pani rączki ucałuj-

Twój Witold L. ${ }^{39}$

ASJ-ZS IS PAN, nr inw. 2II8, teczka V-2 L-Ł, k. 983

[Warszawa], 6 X 1947

Kochany Stefanie!- Do „Braci” potrzebować będę składu następującego:

I trąbka
I perkusja (kotły i in.)
I skrzypce I
I [ - - II
I altówka
I wiolonczela
I kontrabas.

Byłbym b[ardzo] szczęśliwy, gdyby mogło się beze mnie obyć na próbie środowej, zyskałbym bardzo na czasie, co wobec faktu, że muszę jechać jutro do Grodziska (wezwanie $\mathrm{R}$ [ejonowej] K[omendy] U[zupełnień]), ma dla mnie duże znaczenie.

Prowizoryczne obliczenie wykazało, że minutaż muzyki do „Braci” wynosi jednak 6'Is”, czyli więcej niż „Powrót Odyssa” i tyle co „Pani Twardowska” ${ }^{\circ}$, a te właśnie słuchowiska brałem pod uwagę, obliczając obecną stawkę w wys. 25000.

Ściskam Cię serdecznie

Witold L.

39 Na rewersie listu ołówkiem ręką Jarocińskiego rozliczenie z sumą „nad kreską” I3.859 zł, z tego: „5.000 Z. Szemplińska, 8.650 Witold, 20I opłaty pocz[towe], 6 blankiety, 2 zł. dla mnie”.

40 Przytoczone tu tytuły to słuchowiska Teatru Polskiego Radia, do których Lutosławski skomponował oprawę muzyczną: Bracia Jerzego Pytlakowskiego w reżyserii Reny Tomaszewskiej i Bronisława Dardzińskiego, wyemitowane w październiku 1947 r. (zachowana partytura i tekst sztuki), Powrót Odysa Aleksandra Maliszewskiego w reżyserii Jana Koechera, wyemitowane we wrześniu 1945 r. (zachowany tekst słuchowiska), Pani Twardowska Aleksandra Maliszewskiego na podstawie Adama Mickiewicza w reżyserii Bronisława Dardzińskiego, wyemitowane we wrześniu I945 r. (zachowana partytura, tekst i nagranie). Wszystkie informacje podaję za: W. Muras, Twórczość użytkowa, zob. tabela na s. II7-I22. 


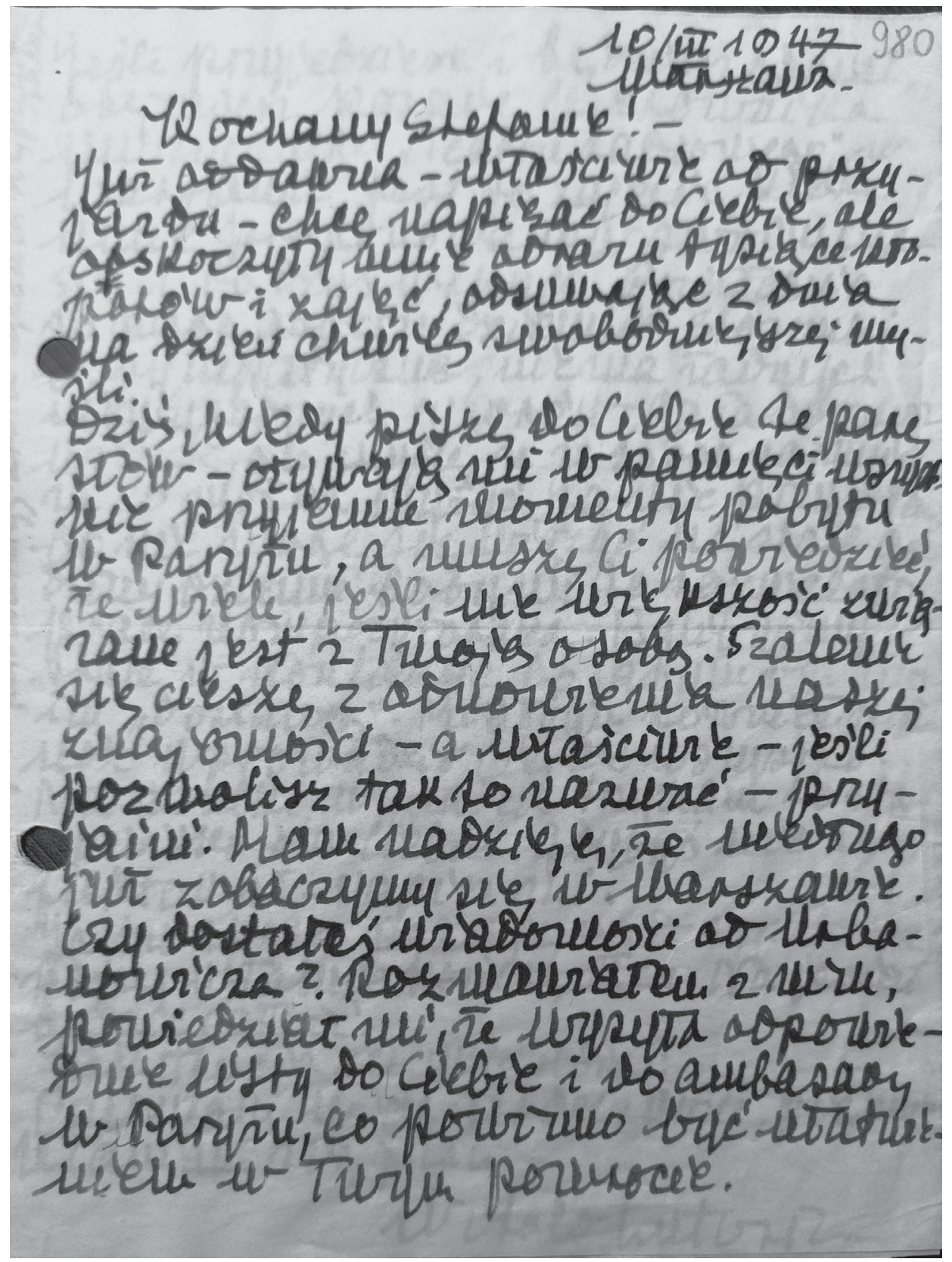

Il. 4a. Lutosławski do Jarocińskiego z Warszawy, Io III 1947 r., rkp. zach. w ASJ-ZS IS PAN, nr inw. 2II8, teczka V-2, L-€, k. 980 (recto) 


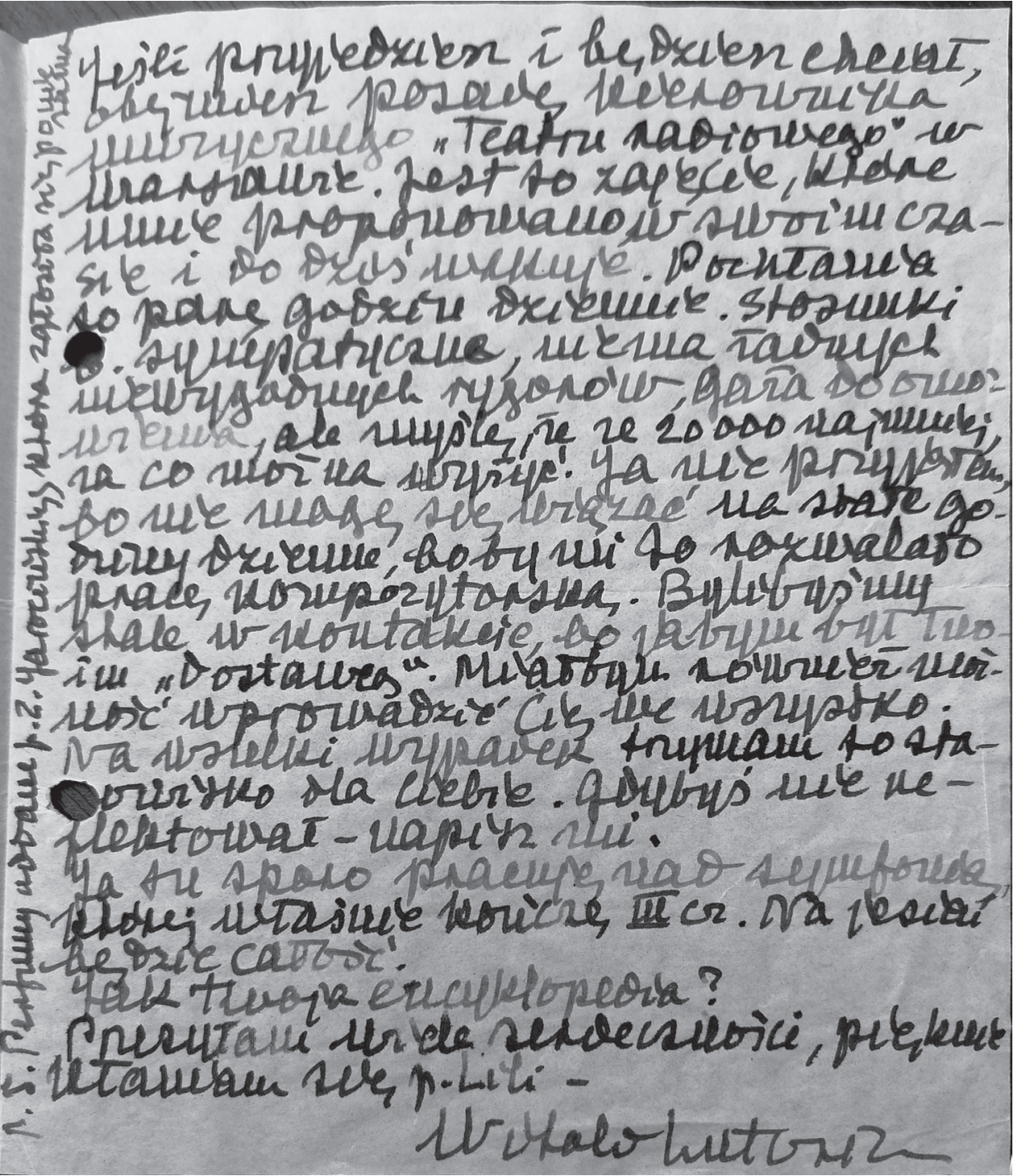

Il. 4b. Ibid., (verso). 
ASJ-ZS IS PAN, nr inw. 2II8, teczka V-2 L-Ł, k. 986

Kochany Stefanie!-

Katowice, 23 III I948

Właśnie przyjechałem z Zakopanego do Katowic, gdzie jestem gościem „Ficiów”. Jutro rozpoczynają się próby Symfonii. Nie mogę odżałować, że nie będzie Cię tutaj na koncercie. Żarliwie pragnę Twego oddźwięku na moją pisaninę, mam nadzieję, że posłuchasz przez radio i nie oszczędzisz mi swych uwag, prawda? To będzie we czwartek, I IV o g. $2 \mathrm{I}^{30}$. Niestety dużo tam będzie muzyki nieradiofonicznej: nie tylko tutti, ale także i inne fragmenty, jak początek III cz. będą na pewno zniekształcone. Ale zawsze - jakieś ogólne wrażenie pozostanie ${ }^{41}$.

Byłem w Krakowie, słyszałem Koncert na 2 fort[epiany] Michała. Jest to z pewnością kawał dobrej muzyki, ale powstrzymuję się z jakimiś bardziej stanowczymi sądami, to za mało raz usłyszeć.

Ostatecznie wycofałem się z praskiego festiwalu. Chyba gdyby po raz drugi zaproszono Fitelberga i zgodził się ${ }^{42}$.

Podobno przyjazd Michała nie jest bardzo pewny, bardzo bym się martwił, gdyby miał nie dojść do skutku ${ }^{43}$.

Będę tu 3 dni, wracam na same święta do Zakopanego, po czym na 3 próby znów przyjeżdżam. Ten „wypoczynek” jest mało intensywny wobec ciągłego podróżowania.

Jak się miewasz? Jakie są twe projekty na przyszłość najbliższą? Cieszyłbym się bardzo z paru słów od Ciebie. Rączki Pani Lilli ucałuj, Ciebie ściskam serdecznie

Katowice: Dyr. Grzegorz Fitelberg, Polskie Radio, Ligonia 29 (dla W.L.)

Twój Witold

Zakopane: „Stylowa”, ul. Grunwaldzka

4I Koncert miał charakter zamknięty, ale wykonanie było doskonałe. Warto dodać, że kilka dni po tym wydarzeniu Lutosławski pisał z wdzięcznością do Fitelberga: „Jestem wciąż pod wrażeniem tych dni niezwykłych, jakie Tobie mam do zawdzięczenia. Góruje we mnie uczucie podziwu dla Twej wielkiej intuicji - potrafiłeś w tak krótkim czasie wniknąć we wszystkie moje intencje i dać wykonanie czyste. Trafne i przy tym pełne własnej siły! [...] Tak więc Ficiu - dziękuję Ci stokrotnie za to przeżycie jedyne w swym rodzaju, za Twój zapał i za tyle serca okazanego i mnie i mej muzyce", Witold Lutosławski do Grzegorza Fitelberga z Warszawy, 4 IV 1948 r., cyt. za: Korespondencja Grzegorza Fitelberga z lat 194I-I953, wybór, opr. i red. Leon Markiewicz, Katowice 2003, s. II6.

42 Grzegorz Fitelberg po raz pierwszy był zaproszony na festiwal Praska Wiosna w I949 roku. I5 maja Česká filharmonie pod jego batutą wykonała II Symfonię B-dur op. I9 Szymanowskiego. Lutosławski zaprezentował się w Pradze trzy lata później, wysyłając w I95I r. swoją Mata suitę polską. Wykonana była ona podczas koncertu 3I maja, na który składały się utwory kompozytorów polskich: poza suitą Lutosławskiego, uwertura do Krakowiaków i górali Jana Stefaniego-Grzegorza Fitelberga, także w opracowaniu Fitelberga uwertura do Parii Moniuszki, Koncert fortepianowy f-moll op. 2I Chopina (fortepian Stanisław Szpinalski) i Symfonia C-dur Tadeusza Bairda, zob.: Pražské jaro, https://festival. cz/o-nas/archiv/, dostęp 20 IV 2020.

43 Michał Spisak był w Polsce na przełomie kwietnia i maja, kiedy to m.in. trzymał do chrztu syna Stefana Jarocińskiego, Michała Marka, zob. też przyp. I3. 
ASJ-ZS IS PAN, nr inw. 2II8, teczka V-2 L-Ł, k. 987

Kochany Stefanie

Paryż, 3 XI 1948

Jestem od paru dni w Paryżu i jakoś niespecjalnie się rozkoszuję tym pobytem. „Nasza” dzielnica - Battignoles - opustoszała i martwa od czasu, jak jej nie zamieszkujesz. Bardzo mi chodzą po głowie nasze rozmowy i spotkania sprzed 2 lat, wieczór wigilijny, spacer do St.-Germain-en-Laye etc. Teraz cała moja nadzieja w Michale [Spisaku], obok którego mieszkam. On - jak zawsze - serdeczny i miły, aż się boję, żeby go zanadto nie nudzić swym towarzystwem. Dziś idziemy - środa - do Nadii Boulanger. Chętnie ją zobaczę mimo całej „ciociowatej” atmosfery jej domu i otoczenia. Spodziewam się tam zobaczyć Antka [Szałowskiego], z którym się nie widziałem dotąd.

Muzyki w Paryżu prawie żadnej, oprócz normalnej szarzyzny niedzielnych koncertów. To robi wrażenie jakby wagonu odstawionego na bocznicę. $\mathrm{Z}$ nudów, żeby coś robić, chodzę na byle co, koncerty Société des Concerts lub opera komiczna (balet Milhauda, Kamma Debussy'ego, Amor bruho de Falli $\left.{ }^{44}\right)$. W „Guide du Concert” nic ciekawego w najbliższe 2 tygodnie. National wyjechała do Ameryki z [Charlesem] Münchem ${ }^{45}$, tak że radiowe koncerty nie zaczną się przed styczniem. Wszystko to - to jak gdyby przeciwwaga przemiłego okresu, jaki spędziłem u Witków Małc[użyńskich] koło Grasse ${ }^{46}$. Opio - malutka miejscowość 7 km koło Grasse - to uroczy, pełen wesołości zakątek, z którego w pogodne dni widać morze. Trochę wyżej, z Châteauneuf - widać olbrzymi kawał brzegu, od Esterelle aż do włoskiej granicy. Siedziałem tam 6 tygodni, odpoczywając i pracując. Korzystałem z sąsiedniej willi, aby nie słyszeć fortepianu Witka. I rzeczywiście mogłem rozkosznie pracować. Robiliśmy trochę wycieczek autem - do Cannes wzdłuż całego wybrzeża, aż do Menton, parę razy byliśmy w Monte Carlo, cudownym, operetkowym mieście. Po tym cudownym kraju Paryż wydaje się doprawdy smutnym miastem. Spędzę tu mimo wszystko parę tygodni i wrócę w pierwszych dniach grudnia.

Bardzo byłbym ciekaw nowin od Ciebie, mam nadzieję, że napiszesz parę słów. Ściskam Cię serdecznie, Lilce ręce całuję

Paris $6^{\mathrm{e}}$

Twój Witold

II, rue de Vaugirard

44 Właściwie: Claude Debussy, Khamma, muzyka do baletu pisana w l. I9II-I2. Debussy nie dokończył dzieła, autorem orkiestracji był Charles Koechlin. Manuel de Falla, El amor brujo (I9I4-I5), balet do libretta Gregoria Martíneza Sierry.

45 Orchestre national de France pod batutą Alzatczyka, Charles’a Müncha, używającego także francuskiej wersji nazwiska - Charles Munch. Urodzony w Strasburgu, od I933 r. (także w latach wojny) artystycznie związany był z Paryżem. Potem, w 1. 1949-62 był dyrektorem Boston Symphony Orchestra.

46 Mowa o letniej posiadłości wynajętej przez Witolda Małcużyńskiego i jego żonę, pianistkę Colette Gaveau. 
ASJ-ZS IS PAN, nr inw. 2II8, teczka V-2 L-Ł, k. 989

Kochany Stefanie!-

Warszawa, I3 XII 1948

Przed wyjazdem z Paryża dostałem Twój list, list bardzo przejmujący, który zapadł mi głęboko w świadomość; będę go wyciągał zawsze w chwilach ciężkich i czytał go dla otuchy. Dzięki Ci - Stefanie - że tak myślisz jakeś mi napisał.

Miałem nadzieję, że zaraz po przyjeździe Cię zobaczę, dlatego też nie odpisywałem. A tu tymczasem tydzień minął i nie ma Cię jeszcze w Warszawie. Co z Tobą? Słyszałem, że masz anginę, czy to się jeszcze wlecze? Czy jesteś już na tyle dobrze, że można by Cię odwiedzić? Napisz słówko.

Ściskam Cię serdecznie, Lilce ręce całuję

Twój Witold

ASJ-ZS IS PAN, nr inw. 2II8, teczka V-2 L-Ł, k. 990

Kochany Stefanie!-

Jarosławiec, I5 VIII 1949

Bardzo Ci dziękuję za kartę z Rapperswilư7, chciałbym Cię prędko zobaczyć i szerzej pogadać. Tyle się gromadzi spraw dużej wagi, ciężko je przeżuwać samotnie, bez konfrontacji. A przy tym wyczuwam, że znalazłbym u Ciebie potwierdzenie mego stanowiska, jakie usiłuję zajmować wobec wszystkiego, co dzieje się w naszej sztuce. Takie to jakieś trudne i odpowiedzialne! W momentach trudnych często sięgam myślą do tego kredytu, jakim mnie obdarzasz i czerpię z niego wiele.

Dostaliśmy wiadomość o śmierci Antoniego Dygata, mego teścia. Umarł na serce w San Paulo $^{48}$. Nowy cios dla Danusi; stara się go znosić mężnie, ale niestety sam organizm nie wytrzymuje tego i sił fizycznych nie starcza.

Wydycham tu zmęczenie po zjeździe w Łagowie, niezmiernie wyczerpującym ${ }^{49}$. Wróciliśmy ok. ${ }^{2}{ }^{g o}$. Mam nadzieję, że moja nieobecność w Radio nie narobiła zbyt dużo kłopotu.

47 W połowie $1949 \mathrm{r}$ r. Jarociński spędził kilka tygodni w szwajcarskim Rapperswilu w związku z organizowaną w Muzeum Polskim (wówczas Muzeum Polski Współczesnej) wystawą z okazji Roku Chopinowskiego, której był komisarzem z ramienia Ministerstwa Kultury i Sztuki.

48 Antoni Dygat (ur. 1886), polski architekt, ojciec Danuty Lutosławskiej z d. Dygat i pisarza Stanisława Dygata. Zmarł w brazylijskim Sao Paulo Io VII 1949 roku.

49 W tych latach Lutosławskiego niejednokrotnie dotykały bezpardonowe, oparte jedynie na przesłankach ideologicznych, krytyki, np. ze strony aktywnego wówczas publicysty Jerzego Kuryluka (piszącego na łamach gazet codziennych - Dziennika Ludowego, Expresu Wieczornego), kolegów po fachu, Jana Maklakiewicza i Witolda Rudzińskiego (podczas zjazdu ZKP w 1949 i 1950 r.), czy samego Włodzimierza Sokorskiego. Z drugiej strony miał wielu stronników m.in. w kręgu redakcji Ruchu Muzycznego czy w środowisku akademickim i muzycznym (Wawrzyniec Żóławski, Aleksander Jackowski, Henryk Swolkień, z czasem Zofia Lissa), którzy sprzeciwiali się czystej propagandzie w ocenach dorobku młodego kompozytora. Bardzo ciekawe światło na tę rozmaitość poglądów na temat Lutosławskiego w socrealistycznej rzeczywistości rzuca Sławomir Wieczorek w artykule „Od «kakofonii dźwięków» do «wielkiej muzyki». Krytyka muzyczna socrealizmu o muzyce Witolda Lutosławskiego”, http://www. resfactanova.pl/pliki/archiwum/numer_23/RFN23\%20Wieczorek\%20-\%20Od\%2okakofonii\%20 dzwiekow\%2odo\%2owielkiej\%2omuzyki.pdf, dostęp 23 VI 2020. 
Szczerze mówiąc, gdyby nawet... to nie krępuje mnie to zbytnio po ostatnich radiowych posunięciach wobec mnie (wymówienie, etc.).

Cieszę się na zobaczenie Was, ściskam Cię serdecznie, Lilce rączki całuję

Twój Witold

ASJ-ZS IS PAN, nr inw. 2II8, teczka V-2 L-Ł, k. 993

[Warszawa], 6 X 1950

Kochany Stefanie,

Zosia Z. wcale nie zadzwoniła, może znów jest chora. Jaki jest jej adres, niech Lila będzie tak dobra mi go przetelefonować, dobrze?, a Danusia pójdzie do Zosi i poprosi o spowodowanie tej interwencji w szpitalu.

Myślimy dużo o Tobie i ściskamy serdecznie, do zobaczenia!

Twój Witold

ASJ-ZS IS PAN, nr inw. 2II8, teczka V-2 L-Ł, k. 994

Warszawa, 3I XII I950

Kochany Stefanie,

Sam nie wiem, od czego zaczynać, taki szmat czasu nie widzieliśmy się! Strasznie Cię zaniedbałem - boli mnie to bardzo - ale nasze życie w ostatnich czasach obfituje w takie troski i smutki, że trudno mi było w tym „zapędzeniu” nawet się odezwać. Marcin chory, przebywa uciążliwą kurację w domu z leżeniem, dietą etc. Danusia troska się nim straszliwie, na domiar wszystkiego miała powtórnie zakażenie w palcu, zdjęto jej paznokieć (ten sam, który zdążył już podrosnąć!), matka w szpitalu, 2 x na tydzień ją odwiedzam, gospodyni miała operację ucha, gorączkę, tydzień na penicylinie. Oto moje życie - barwne, jak widzisz, nie pozbawione rozrywek. Do tego kilka audycji w radio - istny kołowrót. Wszystko to do kupy mogłoby mnie do reszty pozbawić ochoty na cokolwiek, a tymczasem na przekór wszystkiemu pracuję pełną parą i nie ma dnia, żeby coś nie przybyło do mojego „Koncertu na orkiestrę”. Miesiąc temu skończyłem I cz., od tego czasu napisałem kawał finału i zarysowałem jego całość. Środkowe części pozostawiam na później, bo I cz. i finał to filary całej budowli i chcę je mieć najpierw ${ }^{50}$.

Co dzieje się z Tobą?, poza krótkim spotkaniem z Lilą w radio nie mam o Tobie żadnej wieści. Napisz bodaj słówko, błagam Cię, bardzo się stęskniłem do Ciebie, kiedy się zobaczymy? Nie wiem nawet, gdzie jesteś, dla pewności piszę do Milanówka.

so Koncert na orkiestrę ostatecznie ukończony został w roku 1954, prawykonanie - w wykonaniu Orkiestry Symfonicznej Filharmonii Warszawskiej pod batutą Witolda Rowickiego - odbyło się w listopadzie I954 roku. Entuzjastyczne opinie na temat tej kompozycji wyraził na łamach prasowych nie tylko Jarociński („Wielka muzyka”, op. cit.), lecz także Jerzy Broszkiewicz („Wyznania prywatne”, Przegląd Kulturalny 4 (I955) nr I, s. 5), czy niejednokrotnie Zofia Lissa (zob. w: Przegladd Kulturalny 4 (I955) nr 8, s. 5; Muzyka 6 (1955) nr 3-4, s. 25-52; Studia Muzykologiczne 5 (1956), s. 196-299). 
Miałem list od Michała [Spisaka], całkiem dobrze się z nim dzieje, miał nawet zamówienia na muzykę. Zasadniczo narzeka na to, ale moim zdaniem w jego sytuacji zamówienia w Paryżu to sukces.

Napisz bodaj słówko, czekam z utęsknieniem na to, tymczasem ściskam Cię serdecznie, Lilce ręce całuję

Twój Witold

ASJ-ZS IS PAN, nr inw. 2II8, teczka V-2 L-Ł, k. 995

Warszawa, 6 II i95I

Kochany Stefanie,

Właśnie skończyłem terminową robotę (symfoniczną wersję „Małej suity [polskiej]” - do druku) i chciałbym wreszcie Cię zobaczyć. Czy będziesz jeszcze długo w Otwocku, chciałbym Cię odwiedzić.

Jak się czujesz? U nas stare biedy; nie piszę dłużej - odkładam do zobaczenia się z Tobą. Napisz słówko! Tymczasem serdecznie Cię ściskam

Twój Witold

ASJ-ZS IS PAN, nr inw. 2II8, teczka V-2 L-E, k. $997^{51}$

Warszawa, 20 XI 1953

Do zespołu redakcyjnego

"Przeglądu Kulturalnego"

$\mathrm{w} / \mathrm{m}$

Z wielką przykrością przeczytałem w n-rze 45 (63) „Przeglądu Kulturalnego” felieton ob. Gaworskiego pt. „Na muzycznej fali czyli 3 x to samo”. Napastliwy i lekceważący ton w stosunku do tak wybitnego artysty, jak Władysław Szpilman, nonszalancja, z jaką autor felietonu rozstrzyga zagadnienia, na których znać się nie może (np. czy kompozytor tzw. „muzyki poważnej” potrafi napisać „lekką” piosenkę), posługiwanie się nazwiskami kompozytorów (w tej liczbie i moim) dla opisu sytuacji najzupełniej wyimaginowanych - wszystko to każe mi ubolewać nad faktem, że felieton ob. Gaworskiego znalazł miejsce na łamach „Przeglądu Kulturalnego", organu Rady Kultury i Sztuki ${ }^{2}$.

5I List do redakcji Przegladu Kulturalnego został opublikowany na łamach tygodnika (2 (1953) nr 48, s. 7), a po latach włączony do zbioru: Witold Lutostawski. O muzyce. Pisma i wypowiedzi, red. Zbigniew Skowron, Gdańsk 20II, s. 44I (tu także dołączona utrzymana w konsyliacyjnym tonie odpowiedź redakcji tygodnika). W pakiecie pism od Lutosławskiego przechowywanych w archiwum Jarocińskiego znajduje się oryginał listu (Jarociński, jak wspomniano, w Przeglądzie Kulturalnym pełnił funkcję szefa działu muzycznego), uznałam więc za zasadne włączenie go do niniejszej edycji.

52 Felieton Henryka Gaworskiego „Na muzycznej fali czyli 3 x to samo” ukazał się na łamach Przegladu Kulturalnego 2 (1953) nr 45, s. 4. Autor pisał: „Wiem [...] że ilościowo największy dorobek w zakresie muzyki lekkiej i masowej ma właśnie Władysław Szpilman. [...] Idzie mi o to, że [w programie radiowym] nie zachowuje się właściwych proporcji. [...] o każdej porze dnia i nocy słyszymy utwory tego kompozytora. [...] Jeśli już tak się przyjęło, że «Na muzycznej fali» wykonywane są utwory jednego kompozytora, niech to nie będzie ciągle ten sam twórca. Ja na przykład osobiście wolę Serockiego, ktoś inny Lutosławskiego, jeszcze inny Olearczyka - poświęcajmy te audycje kolejno różnym kompozytorom”. 
Wobec tego, że czytelnicy felietonu mogli niewątpliwie wyciągnąć z niego wnioski najzupełniej niezgodne z rzeczywistym stanem rzeczy (na co mógłbym dostarczyć konkretnych przykładów), uważam za konieczne sformułowanie mego osobistego poglądu na niektóre sprawy poruszane przez ob. Gaworskiego. Otóż:

I) Uważam twórczość Władysława Szpilmana za prawdziwą ozdobę programów muzyki lekkiej w Polskim Radio. Władysław Szpilman ma ponadto wybitne zasługi w pracy redakcyjnej programu muzycznego Polskiego Radia, osiągając stosunkowo wysoki poziom programów muzyki lekkiej. To ostatnie zadanie jest w naszych warunkach specjalnie trudne, jak wiemy bowiem, twórczość w tym zakresie stoi w Polsce na ogół bardzo nisko.

2) Nie pisałem dotąd utworów muzycznych, które by można określić jako muzykę „lekką” lub „rozrywkową” (do tego rodzaju artystycznego nie można zaliczyć kilku napisanych przeze mnie pieśni masowych ani licznych piosenek dla dzieci). Toteż absurdalnym jest żądanie, aby Polskie Radio poświęciło mojej twórczości specjalną audycję pt. „Na muzycznej fali”, ponieważ takie moje utwory, jakich wymaga program tego rodzaju audycji, po prostu nie istnieją.

Łączę wyrazy poważania

Witold Lutosławski

ASJ-ZS IS PAN, nr inw. 2II8, teczka V-2 L-Ł, k. 999

Kochany Stefanie,

Warszawa, 30 VIII I955

Ślę Ci najlepsze myśli i życzenia na Dzień Twych imienin [2 września - M.S.]. Mam nadzieję, że odpoczywasz i nabierasz sił i zdrowia. Czy aby wszystko u Was dobrze? Napisz słówko, jeśli jeszcze tam masz zamiar siedzieć, chciałbym bardzo wiedzieć coś o Was. Dzięki serdeczne za depeszę, z której wiem przynajmniej, że żyjesz.

Czy wiesz, że Michał [Spisak] wziął ślub z Andrée $e^{53}$ i pojechali do Hiszpanii?

Ja już jestem po urlopie, który trwał I 8 dni, ale był niezwykle udany: cały ten czas pływaliśmy po Wiśle (do Kazimierza, $3^{1 / 2}$ dnia i z powrotem) przy pięknej pogodzie. Po powrocie do W[arsza]wy chodzę często na przystań, grzebię przy mojej łodzi, czekam na lepszy wiatr, żeby trochę znowu popływać. Nie pracuję, nagrywam tylko muzykę do Dziadów dla radia ${ }^{54}$. I6 IX wyjeżdżam do Liège na konkurs kwartetów (zaprosili mnie do jury)5s.

Czekam na jakieś wiadomości od Ciebie, ściskam serdecznie - ucałuj rączki Lilce i uściskaj dzieci

Twój Witold

Żoną Michała Spisaka była Francuzka Andrée Thibault.

Słuchowisko Dziady Adama Mickiewicza z tekstem w opr. Aleksandra Maliszewskiego wyemitowane zostało w listopadzie 1955 roku. Zachowały się nuty i nagranie, zob.: W. Muras, Twórczość użytkowa, s. I2I.

55 Concours international de quatuor à cordes organizowany był w belgijskim Liège od roku 195I; wówczas pierwszą nagrodę - za IV Kwartet smyczkowy - otrzymała Grażyna Bacewicz. 
ASJ-ZS IS PAN, nr inw. 2II8, teczka II-5D W. Lutosławski monografia i inne teksty, bez numeracji $\mathrm{kart}^{56}$

Kochany Stefanie,

Wiedeń 23 IX 196I

Siedzę w muzeum, Danusia odpoczywa obok mnie na kanapie. Piszę na tym, co mam pod ręką - więc wybacz mi formę tego listu. Znajdziesz w nim odpowiedzi na resztę Twych pytań, wyrażone czasem skrótowo, ale chyba dosyć wyczerpująco.

Ściskamy Cię oboje b[ardzo] serdecznie

Twój Witold

I) Rozmieszczenie części aleatorycznych [w Grach weneckich]:

(Cz. I) odcinki aleatoryczne ACEG, zaś „normalne”, jednak z pewnymi swobodami BDFH (docinki grane przez smyczki). Porządek wykonania: ABCDEFGH. Czyli na przemian aleatoryczne i nie.

(Cz. II) właściwie cała „normalna”. Tylko przy końcu krótka interwencja fortepianu „ad libitum” na tle „normalnym”.

(Cz. III) Cała grana chronologicznie, jednak flet solo gra z zupełną swobodą i reszta ma się do niego stosować, przy czym dyrygent sugeruje tylko początki odcinków (różnej długości od 5" do 20”). Instrumenty nie mogą wykroczyć poza ramy poszczególnych odcinków, jednak wewnątrz nich grają ze swobodą. Wszystkie nuty są jednak zawsze wypisane.

(Cz. IV) Wstęp i kulminacja tej części są „normalne”. Cała partia środkowa i zakończenie składa się z „przedmiotów dźwiękowych” - „objects sonores”, które następują po sobie, przenikają się lub piętrzą jedne nad drugimi. Początek każdego „przedmiotu” jest sygnalizowany przez dyrygenta, wewnątrz „przedmiotu” jednak panuje swoboda - tzn. instrumentalistów nie obowiązuje precyzyjne trzymanie „pionu”, ich partie mogą być lekko przesunięte „w prawo" lub „w lewo”.

2) Pierwsze zastosowanie tej techniki dało mi poczucie wyzwolenia z ryzów, jakie czułem dotychczas bardzo dotkliwie i jakie hamowały poważnie rozwój mego myślenia muzycznego. Znalazłem sposób na to, aby pewne dźwiękowe wyobrażenia, które nurtowały mnie od dawna, móc zrealizować w sposób odpowiadający rzeczywistym możliwościom grających na instrumentach żywych ludzi.

3) W związku z tym widzę możliwość rozwijania dalej tej techniki w najbliższej i dalszej przyszłości. Mam uczucie (które oby nie było tylko złudzeniem), że szyb wiercony cierpliwie w ciągu lat trafi na źródło, z którego wreszcie uda mi się czerpać przez czas dłuższy.

4) ${ }^{57}$ Technika „Gier weneckich” nie ma żadnych ścisłych związków z dodekafonią i serializmem. Jedynie w „Muzyce żałobnej” posłużyłem się serią I2tonową, którą zresztą operowałem w sposób daleki od klasycznego i - co ważniejsze - dla osiągnięcia zupełnie odmiennego rezultatu. Później zarzuciłem (w 5 pieśniach [do słów Kazimiery Iłłakowiczówny], utworach koncertowych i „Grach [weneckich]”) zupełnie serię. Podstawową jednostką, jaką operuję w mych ostatnich rzeczach, jest dwunastodźwięk, czyli „pionowa” agregacja wszystkich dźwięków skali - zjawisko harmonicznej natury. Istnieje - jak wiadomo - praktycznie nie-

56 List spisany został na zadrukowanych kartkach broszurki z informacjami na temat wiedeńskich instytucji kultury i sztuki (lokalizacja, terminy otwarcia, zasób). Jak wspomniano powyżej, fragmenty listu Jarociński wykorzystał niemal dosłownie lub cytował wręcz w artykule „Indywidualność Lutosławskiego” (op. cit.).

57 W oryginale punkt 5 . 
ograniczona możliwość tworzenia coraz to innych dwunastodźwięków. Jednak w mej technice używam przede wszystkim takich, które posiadają dla mnie określoną i charakterystyczną fizjonomię ekspresyjną, kolorystyczną i - co za tym idzie - swoistą strukturę. Między poszczególnymi rodzinami dwunastodźwięków istnieją nieraz ostre kontrasty. Gra tych kontrastów jest m.in. jednym z podstawowych elementów mej techniki.

Jak widać - nie ma to nic wspólnego z dodekafonią i serializmem. Punkt wyjścia, sposoby techniczne, a przede wszystkim - cel, wynik, efekt, są zupełnie inne. Jedyna rzecz wspólna, to "total chromatique" 88 .

W dalszym ciągu serializm uważam za zjawisko pierwszorzędnej wagi w historii muzyki. Jednak jest to metoda prowadząca do efektów zupełnie mi obcych i dlatego trudno mi sobie wyobrazić, abym się do niej kiedykolwiek miał zbliżyć.

Czuję, że wszystko, co piszę, nie ma właściwie związków z tradycją wiedeńską (Sch[önberg], Web[ern]). Dużo bardziej czuję się związany z nurtem Debussy - Strawiński - Bartok - Varèse - 59

58 Kilka lat później, przy okazji omawiania swojego Kwartetu smyczkowego, o Grach weneckich mówił tak: „Już pisząc Jeux vénitiens natknąłem się na zasadniczą trudność, jaka powstaje, gdy chcemy zanotować w formie partytury muzykę zespołową przeznaczoną do wykonania ad libitum. W muzyce takiej bowiem nie ma ani wspólnego dla wszystkich wykonawców pulsu, ani wspólnych taktów, ani jakichkolwiek innych czynników, które usprawiedliwiałyby zapisanie jednej partii nad drugą w ten właśnie, a nie w inny sposób. Celem partytury jest m.in. unaocznienie tego, co dzieje się w poszczególnych partiach w każdym dowolnie wybranym momencie utworu między jego początkiem i końcem”, zob. Witold Lutosławski, „Uwagi o sposobie wykonywania mego Kwartetu smyczkowego”, Ruch Muzyczny 9 (1965) nr I7, s. 3-4.

59 W tym miejscu list się kończy. W wypowiedziach Lutosławskiego wybranych przez Stefana Jarocińskiego do Materiatów do monografii (op. cit.) pada wiele nazwisk kompozytorów i współczesnych i reprezentujących różne epoki historyczne, choć akurat bliskie Jarocińskiemu nazwisko Debussy’ego nie jest tu w sposób szczególny wyróżnione, a jeśli pada, to dwukrotnie właśnie w związku z dokonaniami Wiedeńczyków i Strawińskiego. 


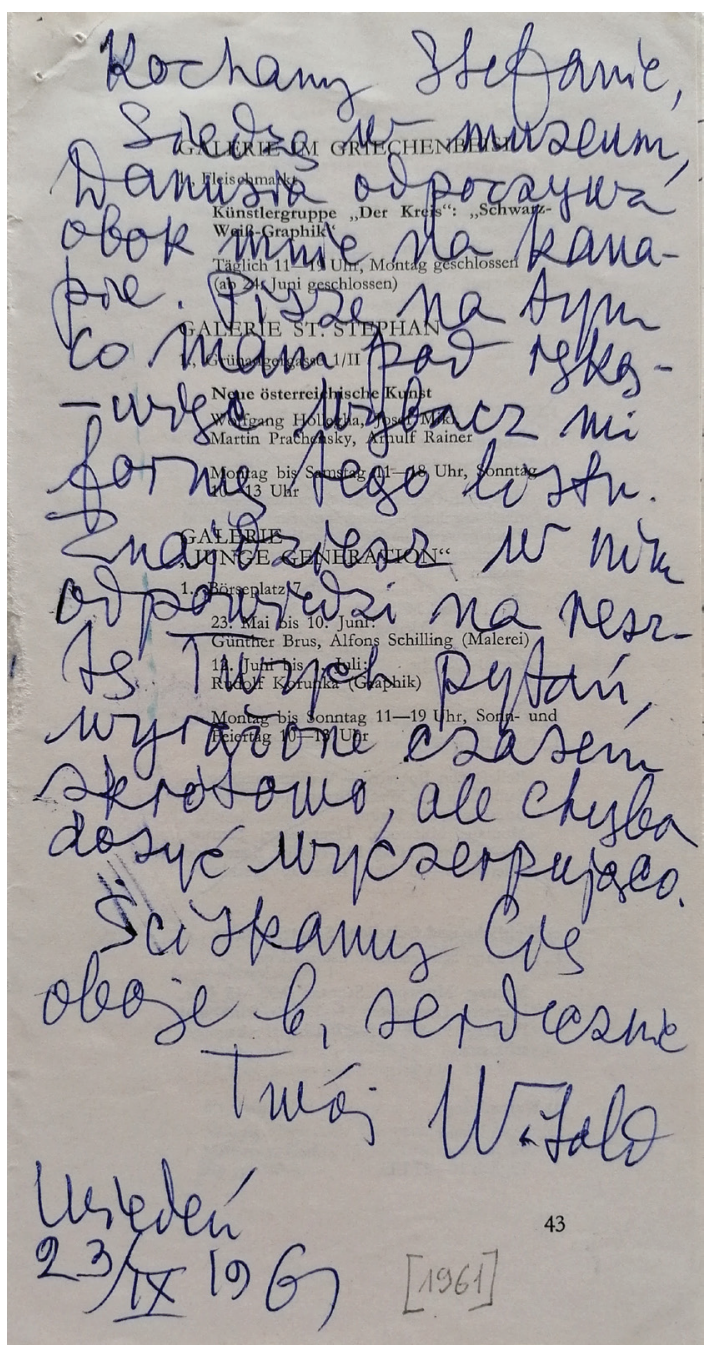

Il. 5a. Lutosławski do Jarocińskiego z Wiednia, 23 IX 196r r., rkp. zach. w ASJ-ZS IS PAN, nr inw. 2II8, teczka II-5D, W. Lutosławski monografia i inne teksty, bez numeracji kart 


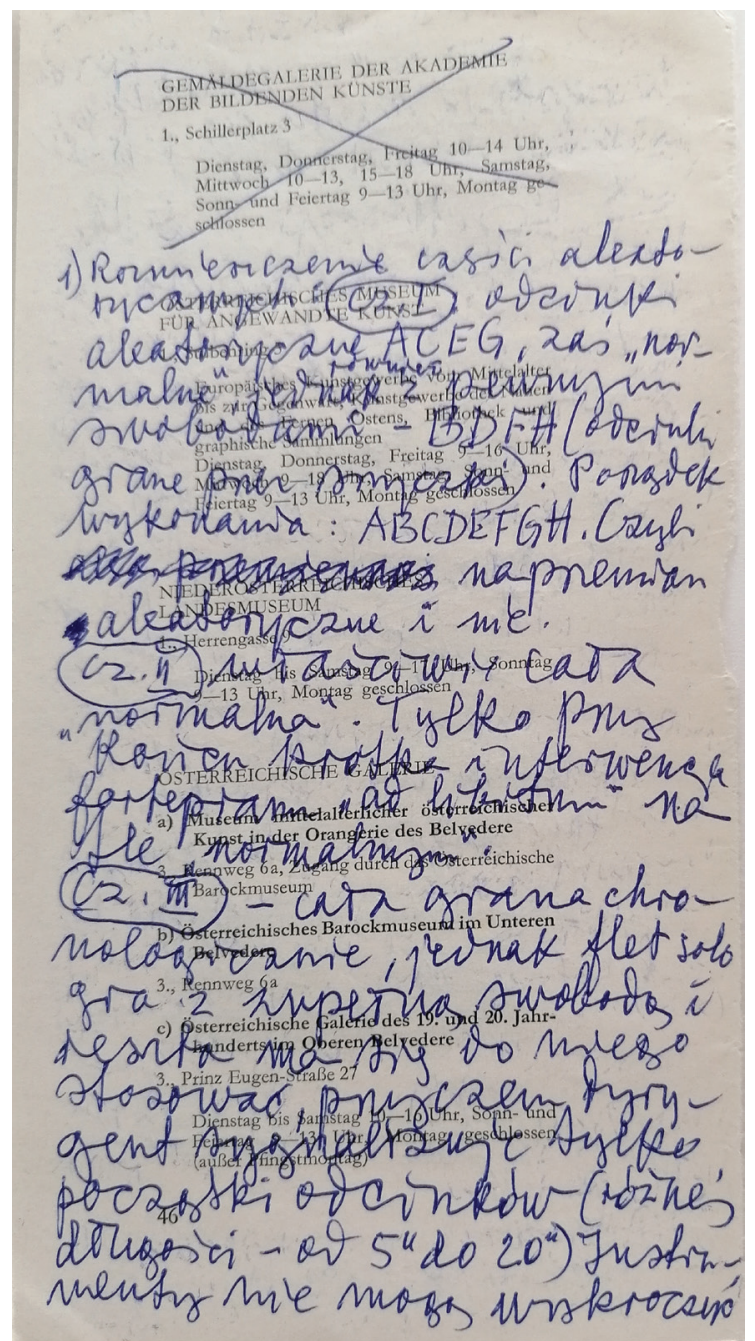

Il. 5b. Ibid. 


\section{BIBLIOGRAFIA}

Broszkiewicz, Jerzy. „Wyznania prywatne”. Przeglad Kulturalny 4, nr I (I955): 5.

Gaworski, Henryk. „Na muzycznej fali czyli 3 x to samo”. Przeglad Kulturalny 2, nr 45 (1953): 4.

Gwizdalanka, Danuta, Krzysztof Meyer. Lutostawski. Droga do dojrzatości. Kraków: PWM, 2005.

Jarociński, Stefan, red. Antologia polskiej krytyki muzycznej XIX i XX wieku (do roku I939).

Kraków: PWM, I955 (= Z Prac Państwowego Instytutu Sztuki).

Jarociński, Stefan. „Główne tendencje estetyczne w muzyce XX wieku”. Muzyka I, nr 3 (1956): $3-22$.

Jarociński, Stefan. „Indywidualność Lutosławskiego”, Ruch Muzyczny 5, nr 2I (I96I): 5-6.

Jarociński, Stefan. „Międzynarodowy Festiwal Muzyki Współczesnej w Wenecji”. Ruch Muzyczny 5, nr I2 (1961): I5-I6.

Jarociński, Stefan. „Nowa muzyka Lutosławskiego”. Przeglad Kulturalny 7, nr 22 (1958): 7.

Jarociński, Stefan. „Nowe utwory fortepianowe Lutosławskiego”. Muzyka 4, nr 9-Io (I953): $7 \mathrm{I}-76$.

Jarociński, Stefan. „Tadeusz Kaczyński: Rozmowy z Witoldem Lutostawskim. Kraków 1972 PWM". Muzyka 19, nr 2 (1974): 75-79.

Jarociński, Stefan. „Wielka muzyka”. Przeglad Kulturalny 3, nr 49 (1954): 2.

Jarociński, Stefan. „Witold Lutosławski”. Przeglad Kulturalny I, nr II (I952): 3.

Jarociński, Stefan. Mozart. Kraków: PWM, 1954 (= Małe Monografie Muzyczne 3).

Jarociński, Stefan. Witold Lutostawski. Materiaty do monografii. Kraków: PWM, 1967.

Jarociński, Stefan, Michał Bristiger, „Obrachunki muzyczne. Dialog o zadawnionych i aktualnych sprawach twórczości”. Przeglad Kulturalny 2, nr II (I953): 3.

Lissa, Zofia. „Koncert na orkiestrę Witolda Lutosławskiego”. Muzyka 6, nr 3-4 (I955): 25-52.

Lissa, Zofia. „Koncert na orkiestrę Witolda Lutosławskiego”. Przegląd Kulturalny 4, nr 8 (I955): 5 .

Lissa, Zofia. „Koncert na orkiestrę Witolda Lutosławskiego”. Studia Muzykologiczne 5 (1956): 196-299.

Lutosławski, Witold. „Uwagi o sposobie wykonywania mego Kwartetu smyczkowego”, Ruch Muzyczny 9, nr I7 (1965): 3-4.

Markiewicz, Leon, red. Korespondencja Grzegorza Fitelberga z lat I94I-1953. Katowice: Fundacja Muzyczna Międzynarodowego Konkursu Dyrygentów im. G. Fitelberga, 2003.

Markiewicz, Leon. Michat Spisak I9I4-I965. Dąbrowa Górnicza-Kraków: Muzeum Miejskie „Sztygarka”/Księgarnia Akademicka, 2005.

Markowska, Elżbieta, red. Lutostawski I9I3-2013. Warszawa: Towarzystwo im. Witolda Lutosławskiego, Muzeum Historyczne m.st. Warszawy, 2013.

Muras, Wioleta. „Podążając śladami dźwiękowej wyobraźni. Muzyka Witolda Lutosławskiego w słuchowiskach Polskiego Radia”. Muzyka 6I, nr 2 (2016): 57-84.

Muras, Wioleta. Twórczość użytkowa Witolda Lutostawskiego $w$ świetle jego biografii i w kontekście przemian audiosfery $w$ XX wieku. Wrocław: Wydawnictwo Uniwersytetu Wrocławskiego, 2019.

Owińska, Zofia. Lutostawski o sobie. Gdańsk: Słowo/Obraz Terytoria, 20 Io. 
Pražské jaro, https://festival.cz/o-nas/archiv/, dostęp 20 IV 2020.

Skowron, Zbigniew, red. Witold Lutostawski. O muzyce. Pisma i wypowiedzi. Gdańsk: Słowo/ obraz terytoria, 2011 .

Skowron, Zbigniew. Witold Lutostawski. Zapiski. Warszawa: Wydawnictwa Uniwersytetu Warszawskiego, 2008.

Wieczorek, Sławomir. „Od «kakofonii dźwięków» do «wielkiej muzyki». Krytyka muzyczna socrealizmu o muzyce Witolda Lutosławskiego". http://www.resfactanova.pl/pliki/archiwum/numer_23/RFN23\%20Wieczorek\%20-\%20Od\%2okakofonii\%2odzwiekow\%20 do\%2owielkiej\%2omuzyki.pdf, dostęp 23 VI 2020.

Witold Lutostawski. Baza wiedzy, http://www.lutoslawski.org.pl/pl/composition,67.html, dostęp I7 VI 2020.

TOWARD A HISTORICAL STUDY OF THE FRIENDSHIP BETWEEN STEFAN JAROCIŃSKI AND WITOLD LUTOSŁAWSKI. THE COMPOSER'S LETTERS KEPT IN THE SPECIAL COLLECTIONS OF THE INSTITUTE OF ART, POLISH ACADEMY OF SCIENCES (I947-I96I)

This is a paper presenting materials related to the person and work of Witold Lutosławski, preserved in the archive of Stefan Jarociński (which has been part of the PAS Institute of Art's Special Collections since the autumn of 20I7). The archive includes, among others, I 3 letters which testify to the long-standing friendship between these two eminent personalities, as well as materials collected by Jarociński during his work on publications concerning the person and oeuvre of the composer of Mi-parti.

The friendship between Jarociński, one of the main representatives of the 2nd generation of Polish musicologists, and Lutosławski, who is included in the pantheon of the century's most outstanding composers, is a moving example of relations between great personalities in Polish culture in the 2 nd half of the 2oth century. They had met as students at Warsaw's Stefan Batory Grammar School. Years later the ex-schoolmates became close friends. Their contact was interrupted during WWII. Following the war they first met in Paris (1946), where Jarociński settled after the liberation of Murnau POW camp (Oflag), and where Lutosławski came to attend a UNESCO concert featuring, among others, his Symphonic Variations. Over the period of three months in late 1946 and early 1947 they spent much time together, largely in the Paris neighbourhood of Battignoles, of which the composer grew particularly fond. Shortly after coming back to Poland, on Ioth March 1947 Lutosławski sent his friend a letter, in which he encouraged Jarociński to return and tempted him with the prospect of taking up the then vacant post of journalist in the Polish Radio Theatre. In later letters, the composer shared his impressions of artistic events, but also wrote about his personal life, mentioning, among others, Michał Spisak, who was likewise Jarociński's friend.

Lutosławski's works inspired Jarociński so much that they quite soon became the object of his analyses and studies. He presented the composer's portrait in the inaugural issue of his column 'Artist Profiles' printed in Przeglad Kulturalny [Culture review]. In the same period, Jarociński took up a post at the State Institute of Art (the later PAS Institute of Art), where, apart from studying the history of Polish music criticism and late I9th- / early 2oth-century 
music, he returned several times to Lutosławski's output (in articles and reviews printed in the Institute's periodicals: Muzyka (monthly and quarterly) as well as Studia Muzykologiczne [Musicological studies] and Materiaty do Studiów i Dyskusji z Zakresu Teorii i Historii Sztuki, Krytyki Artystycznej oraz Metodologii Badań nad Sztuka [Materials for the study and discussion of art theory and history, art criticism, and methodology of research on art]. He also planned to write a monograph dedicated to that composer. Lutosławski responded to these frequent manifestations of friendship by dedicating to Jarociński's memory his Grave, which opens with the 'forest motif' from Pelléas et Mélisande, quoted there as a symbolic homage to Jarociński's scholarly passion.

My paper is accompanied by an edition of the 13 previously unknown and unpublished letters written by Witold Lutosławski to Stefan Jarociński in 1947-1961. The study of these documents, in correlation with that of the correspondence between Jarociński and Polish Chopin scholar, musicologist Ludwik Bronarski (preserved at the Polish Catholic Mission in Marly), with which I have been able to become acquainted, has made it possible for me to describe for the first time or shed light on several episodes from the lives of both Jarociński and Lutosławski.

Translated by Tomasz Zymer

Słowa kluczowe / keywords: Witold Lutosławski, Stefan Jarociński, polska muzyka współczesna / Polish contemporary music, historia polskiej muzykologii / history of Polish musicology, życie kulturalne lat pięćdziesiątych / cultural life in the I950s

Dr Małgorzata Sieradz, adiunkt w Zakładzie Muzykologii Instytutu Sztuki PAN w Warszawie. Główny obszar jej zainteresowań badawczych to historia czasopiśmiennictwa muzycznego, historia muzykologii polskiej oraz polska kultura muzyczna XIX i XX wieku. Jest autorką monografii Kwartalnika Muzycznego (2015), przygotowała edycję korespondencji Adolfa Chybińskiego z Józefem Michałem Chomińskim (2016) i z Ludwikiem Bronarskim (t. I cz. I, 2020) oraz listów Bronisławy Wójcik-Keuprulian do Henryka Opieńskiego i Ludwika Bronarskiego (20I8). Przygotowała również i opublikowała (wraz z Tomaszem Chachulskim) edycję Pieśni Józefa Elsnera (wyd. w ramach serii Monumenta Musicae in Polonia, 2018). halina.sieradz@ispan.pl

\section{Archiwalne zeszyty ,Muzyki”}

iswydawnictwo@ispan.pl 